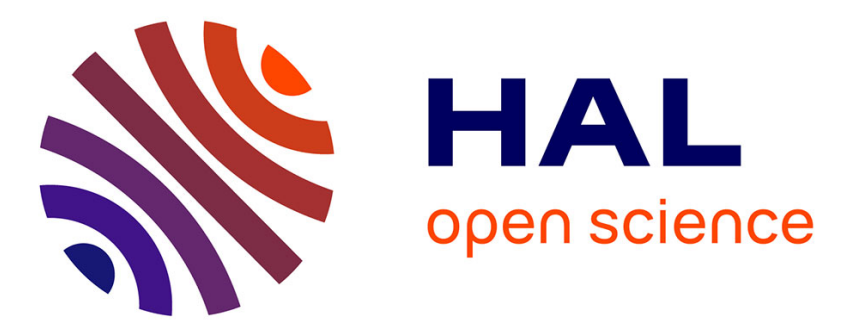

\title{
Large-scale flank collapse events during the activity of Montagne Pelée, Martinique, Lesser Antilles
} Anne Le Friant, Georges Boudon, Christine Deplus, Benoît Villemant

\section{To cite this version:}

Anne Le Friant, Georges Boudon, Christine Deplus, Benoît Villemant. Large-scale flank collapse events during the activity of Montagne Pelée, Martinique, Lesser Antilles. Journal of Geophysical Research : Solid Earth, 2003, 108 (B1), 10.1016/S0377-0273(98)00030-4 . insu-01586208

\section{HAL Id: insu-01586208 https://hal-insu.archives-ouvertes.fr/insu-01586208}

Submitted on 12 Sep 2017

HAL is a multi-disciplinary open access archive for the deposit and dissemination of scientific research documents, whether they are published or not. The documents may come from teaching and research institutions in France or abroad, or from public or private research centers.
L'archive ouverte pluridisciplinaire HAL, est destinée au dépôt et à la diffusion de documents scientifiques de niveau recherche, publiés ou non, émanant des établissements d'enseignement et de recherche français ou étrangers, des laboratoires publics ou privés. 


\title{
Large-scale flank collapse events during the activity of Montagne Pelée, Martinique, Lesser Antilles
}

\author{
Anne Le Friant ${ }^{1}$ and Georges Boudon \\ Laboratoire de Physique des Géomatériaux, CNRS UMR 7046, and Observatoires Volcanologiques, Institut de Physique du \\ Globe de Paris, Paris, France \\ Christine Deplus \\ Laboratoire de Gravimétrie et Géodynamique, CNRS UMR 7096, Institut de Physique du Globe de Paris, Paris, France
}

Benoît Villemant

Laboratoire de Physique des Géomatériaux, CNRS UMR 7046, and Observatoires Volcanologiques, Institut de Physique du Globe de Paris, Paris, France

Received 6 November 2001; revised 5 May 2002; accepted 11 September 2002; published 29 January 2003.

[1] A horseshoe-shaped structure already identified on the southwestern flank of Montagne Pelée (Martinique, Lesser Antilles arc) was previously interpreted as resulting of a flank collapse event, but no debris avalanche deposits were observed at the time. New offshore high-resolution bathymetry and geophysical data (Aguadomar cruise; December 1998 to January 1999; R/V L'Atalante) lead us to identify three debris avalanche deposits on the submarine western flank of Montagne Pelée extending down to the Grenada Basin. They display morphological fronts and hummocky morphology on bathymetric data, speckled pattern on backscatter data and hyperbolic facies on $3.5 \mathrm{kHz}$ and seismic profiles. New on-land geological studies lead us to identify two other horseshoe-shaped structures on the same flank of the volcano. The three submarine deposits have been traced back to the structures identified on land, which confirms the occurrence of repeated flank collapse events during the evolution of Montagne Pelée. The ages of the last two events are estimated at $\sim 9 \mathrm{ka}$ and $\sim 25 \mathrm{ka}$ on the basis of ${ }^{14} \mathrm{C}$ and ${ }^{238} \mathrm{U} /{ }^{230} \mathrm{Th}$ dates. Every flank collapse produced debris avalanches which flowed down to the Caribbean Sea. We propose that the repeated instabilities are due to the large asymmetry of the island with western aerial and submarine slopes steeper than the eastern slopes. The asymmetry results from progressive loading by accumulation of volcanic products on the western slopes of the volcano and development of long-term gravitational instabilities. Meteoric and hydrothermal fluid circulation on the floor of the second flank collapse structure also creates a weakened hydrothermalized area, which favors the recurrence of flank collapses. INDEX TERMS: 3045 Marine Geology and Geophysics: Seafloor morphology and bottom photography; 8414 Volcanology: Eruption mechanisms; 8499 Volcanology: General or miscellaneous; KEYWORDS: Montagne Pelée, Martinique, Lesser Antilles arc, flank collapse, debris avalanche, risk

Citation: Le Friant, A., G. Boudon, C. Deplus, and B. Villemant, Large-scale flank collapse events during the activity of Montagne Pelée, Martinique, Lesser Antilles, J. Geophys. Res., 108(B1), 2055, doi:10.1029/2001JB001624, 2003.

\section{Introduction}

[2] Flank collapse events have now been recognized as an efficient process of volcano destruction. Thus they play an important role in the evolution of volcanic edifices, whatever the geodynamic context in which they occur. The 1980 eruption of Mount St. Helens [Lipman and Mullineaux, $1981]$ is a good example of what can occur on a volcano in

\footnotetext{
${ }^{1}$ Also at Laboratoire de Gravimétrie et Géodynamique, CNRS UMR 7096, Institut de Physique du Globe de Paris, Paris, France.

Copyright 2003 by the American Geophysical Union. 0148-0227/03/2001JB001624\$09.00
}

a very short time. Resulting debris avalanches can run downslope several tens of kilometers. When they occur on volcanic islands they can enter the sea and produce catastrophic tsunamis. In the recent years, numerous flank collapse events have been identified and studied on land on many volcanoes [Siebert, 1984; McGuire, 1996]. Flank collapse events can be repetitive and can mobilize different volumes of material (tenths to hundreds of cubic kilometers). The most voluminous events were recognized on oceanic islands on the basis of marine studies: Hawaii, [Lipman et al., 1988; Moore et al., 1989, 1994], La Réunion [Lénat et al., 1989; Labazuy, 1996], and the Canary Archipelago [Holcomb and Searle, 1991; Watts and Masson, 1995; Urgeles et al., 1997; Krastel et al., 2001; Masson et al., 2002]. 
[3] In the Lesser Antilles arc, which results from the subduction of the Atlantic oceanic crust under the Caribbean plate, several horseshoe-shaped structures were identified on most islands [Roobol et al., 1983; Vincent et al., 1989; Wadge, 1985; Mattioli et al., 1995]. On La Grande Découverte-La Soufrière volcano, Guadeloupe, the horseshoe-shaped structures have been clearly related to debris avalanche deposits on land [Boudon et al., 1984; Boudon et al., 1987] and one event to a lateral blast deposit. Recently, on 26 December 1997, the ongoing eruption of Soufriere Hills on Montserrat generated a small but devastating flank collapse [Robertson et al., 2000]. However, generally in the Lesser Antilles arc, no debris avalanche deposits have been identified and correlated to the large horseshoe-shaped structures recognized on land. Their origin by flank collapse needs to be confirmed.

[4] At the beginning of 1999, we conducted a marine geophysical survey on both flanks of the Lesser Antilles Arc (Aguadomar cruise, R/V L'Atalante) [Deplus et al., 1999]. Analysis of the data has revealed numerous submarine debris avalanche deposits off active volcanoes of Montserrat, Dominica, Martinique, and St. Lucia [Deplus et al., 2001]. The deposits display hummocky morphology on swath bathymetry, a speckled pattern on backscatter images, hyperbolic reflections on $3.5 \mathrm{kHz}$ echo sounder data and diffracting units on seismic data. At the same time, on-land studies on several islands of the arc identified new horseshoe-shaped structures and, in some case, debris avalanche deposits [Boudon et al., 1999] that can be related with the offshore deposits. In this paper, we focus on Montagne Pelée volcano, Martinique. On the southwestern flank of Montagne Pelée, Vincent et al. [1989] previously identified a horseshoe-shaped structure, but no debris avalanche deposits were recognized at the time. The new marine and on-land studies show that Montagne Pelée has experienced at least three flank collapse events during its evolution. We first present the detailed characteristics of the submarine debris avalanche deposits and their relationship with horseshoe-shaped structures and debris avalanche deposits identified on land. We then discuss the origin of the flank collapse events, their ages, and their influence on the sedimentation in the back arc Grenada Basin.

\section{Geological Setting and Previous Data}

[5] Martinique island is located in the central part of the Lesser Antilles arc (Figure 1). The arc has a curved shape and extends over $800 \mathrm{~km}$ from the South American continent to the Greater Antilles. Arc volcanism is active since $40 \mathrm{Ma}$ [Martin-Kaye, 1969; Bouysse et al., 1990]. To the north of Dominica, the arc is divided in two strings of islands. The outer string corresponds to the older part of the arc where thick carbonate platforms cover the volcanic basement of the islands. Active volcanoes are located on the inner string active since $20 \mathrm{Ma}$. South of Dominica, the arc is composed of only one string of islands on which the older and recent parts are superimposed. These islands are bordered to the west by the back arc Grenada Basin, $2900 \mathrm{~m}$ deep. The volcanic activity on Martinique Island covers a period from the early Miocene to present with global migration of the active centers from the southeast to the northwest with time.

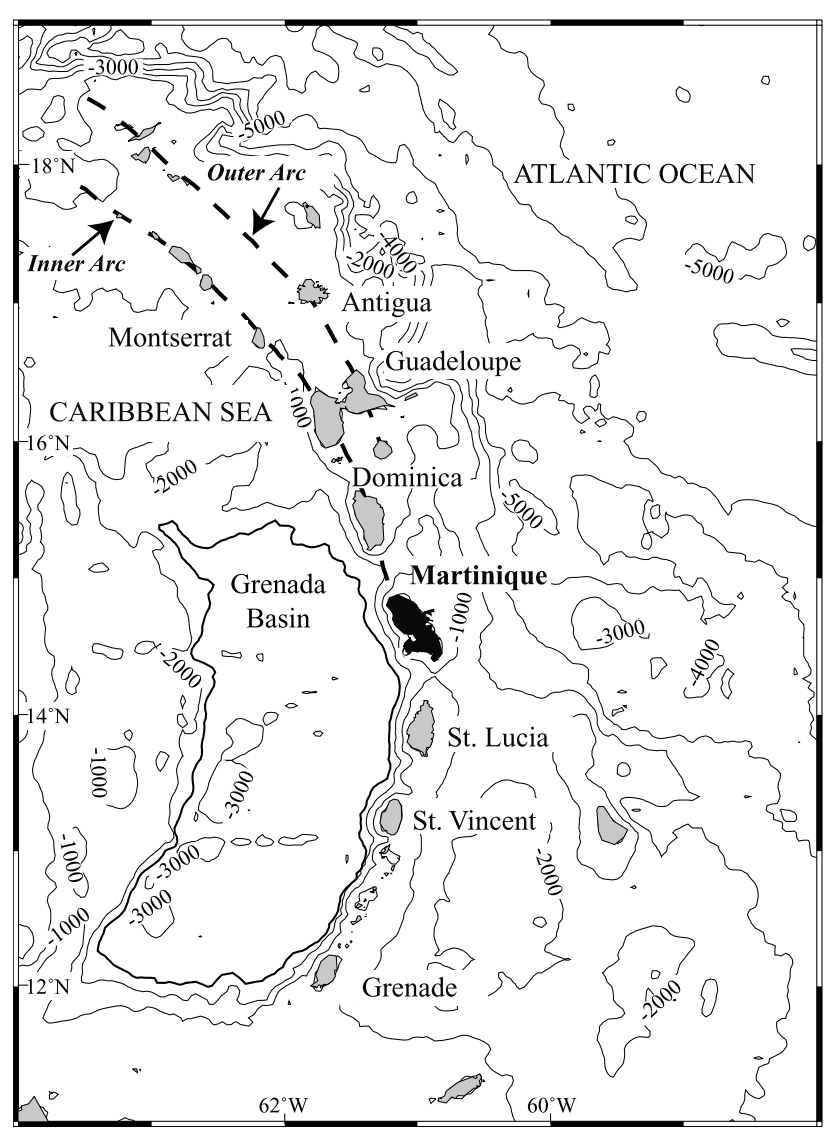

Figure 1. Geodynamic setting of Montagne Pelée volcano (Martinique) in the Lesser Antilles Arc. Predicted bathymetry from Smith and Sandwell [1997]. Contour interval is $1000 \mathrm{~m}$. The Grenada back arc Basin (thick solid line) borders the southern islands of the arc.

[6] Montagne Pelée, located in the northern part of Martinique Island, is an active and dangerous volcano, which has experienced several historical eruptions, including the 1902-1904 and 1929-1932 events. The century's most devastating eruption in 1902 caused the destruction of the towns of St. Pierre and Morne Rouge and the death of 30,000 people [Lacroix, 1904]. The location of the volcano between two older ones (Mont Conil to the northwest and Morne Jacob-Pitons du Carbet to the southeast) (Figure 2) is responsible for the preferential development of the northeastern and southwestern flanks [Vincent et al., 1989; Boudon, 1993]. The evolution of the volcano can be divided in 3 main stages described below [Traineau, 1982; Traineau et al., 1983; Westercamp and Traineau, 1983a, 1983b]. Pyroclastic deposits are dominant compared to massive lavas.

[7] The beginning of the volcanic activity has been dated at about $0.4 \mathrm{Ma}$ [Bellon et al., 1974]. However, on the basis of our new studies and dates, it is likely that it is not older than 0.2-0.3 Ma. The first stage, called "paleo-Pelée" mainly consists of volcanic breccias (block- and-ash flows), viscous lava domes located in the central part of the edifice and few lava flows. The second stage, named St. Vincent period ( $>40,000-19,000$ years B.P.) corresponds to the emplacement of numerous scoria flows resulting from open vent eruptions. A large flank collapse event was proposed to 


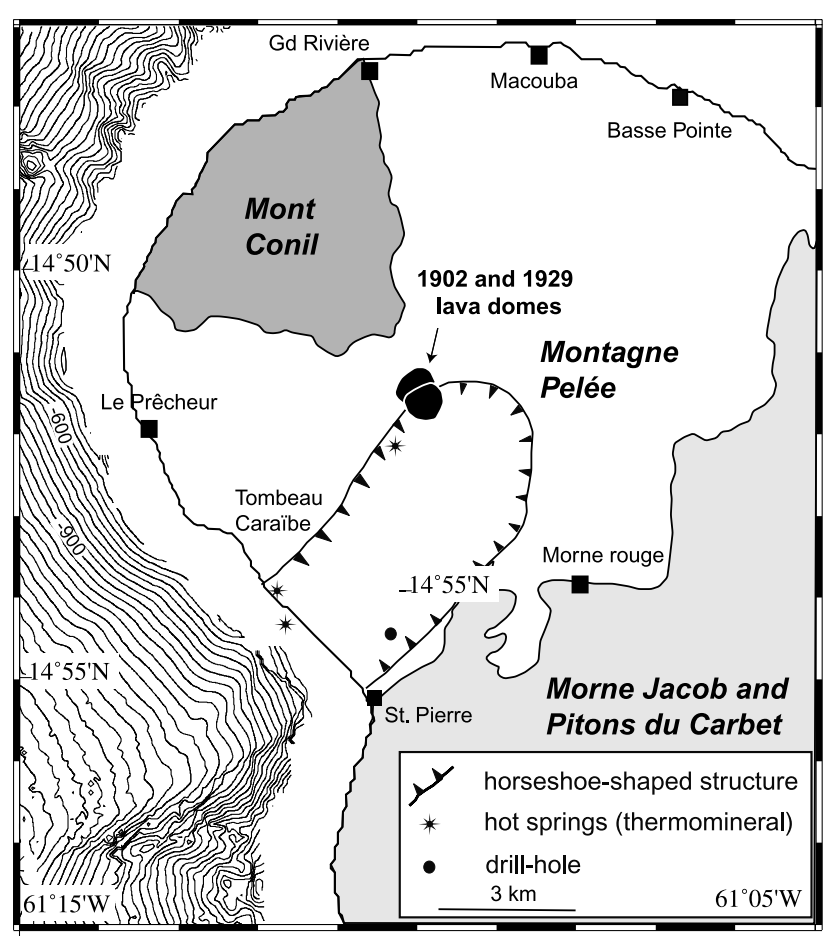

Figure 2. Location of the horseshoe-shaped structure proposed by Vincent et al. [1989] on Montagne Pelée volcano. The active Montagne Pelée volcano is located between two old volcanoes (Mont Conil and Pitons du Carbet-Morne Jacob). Previous swath bathymetry compiled by Le Friant [1998] is also reported (oceanographic cruises: Arcante2, 1980; Dormasis, 1992); contour interval is $50 \mathrm{~m}$.

occur during this stage on the southwestern flank of the volcano [Vincent et al., 1989]. It formed a horseshoe-shaped structure $(6 \times 3.5 \mathrm{~km})$ open to the southwest (Figure 2$)$. Products of the paleo-Pelée stage identified in the walls of the collapse structure are not observed inside the depression which contains only more recent products. No debris avalanche deposits related to the horseshoe-shaped structure were recognized on land. For this event, Vincent et al. [1989] suggested a minimum age of $\sim 25,000$ years B.P., on the basis of the presence of scoria flows channeled inside the structure dated at 25,000 \pm 1040 years B.P. [Traineau et al., 1983]. The third stage, "the modern period" $(14,000$ years B.P. to present) corresponds to the emplacement of the new cone of Montagne Pelée that partially fills the horseshoe-shaped structure and covers its northeastern rim. Two types of eruptions have occurred: pumiceous Plinian eruptions and dome-forming eruptions with associated blockand-ash-flows and pyroclastic surges. During this stage, deposits are mainly concentrated on the southwestern flank of the volcano, inside the horseshoe-shaped structure.

[8] Additional observations are consistent with the existence of the flank collapse event proposed by [Vincent et al., 1989]. On the basis of self-potential (SP) surveys, Zlotnicki et al. [1998] have recognized two SP anomalies on the western flank of Montagne Pelée. An SP negative anomaly $(-900 \mathrm{mV})$ is centered below the horseshoe-shaped structure and vanishes toward its southern rim. It is interpreted as resulting of meteoric water circulation on the floor of the depression between indurate products of paleo-Pelée and unconsolidated deposits of the more recent stages. This water circulation is confirmed by the presence of a well in the southern part of the structure with cold water circulation. A positive SP anomaly $(+100 \mathrm{mV})$ is located in the northwestern part of the depression and interpreted as resulting from hydrothermal water circulation at its floor. This agrees with the emergence of thermomineral springs in the northern part of the structure at an elevation of $650 \mathrm{~m}$ and on the coastline.

[9] A synthesis of swath bathymetry data west of Montagne Pelée (Arcante2, 1980; Seacarib, 1985, and several transits) was conducted [Le Friant, 1998] before the Aguadomar cruise and shows the offshore continuity of the southern rim of the horseshoe-shaped structure (Figure 2). However, the data coverage at the time only extends over the upper submarine slopes of the volcano (shallower than $-2250 \mathrm{~m}$ ) and prevented offshore recognition of possible associated debris avalanche deposits.

\section{Data Collection and Processing}

[10] The marine data were gathered during the Aguadomar cruise, aboard the French R/V L'Atalante (December 1998 to January 1999). We collected Simrad EM12D swath bathymetry and backscatter data, $3.5 \mathrm{kHz}$ echo sounder, gravity, magnetic and 6-channel seismic reflection profiles around several islands of the arc up to $70 \mathrm{~km}$ from the coastlines [Deplus et al., 2001]. Swath bathymetry and backscatter data were processed using the CARAIBES software developed by Ifremer. Digital terrain models (DTM) have been constructed with resolutions of $100 \mathrm{~m}$. The 6-channel seismic reflection data were filtered, stacked and migrated using seawater velocity with "Seismic Unix" software [Cohen and Stockwell, 1996].

[11] Morphological analysis of the island was performed on a 50-m resolution DTM provided by the French National Geographic Institute (IGN) and aerial photographs. In addition, the swath bathymetry was merged with the onland topography to construct a $100-\mathrm{m}$ resolution DTM covering an area of $9.1 \times 9.2 \mathrm{~km}$ on the western submarine and subaerial flanks of Montagne Pelée.

[12] On-land geological investigations were then carried out in order to study the horseshoe-shaped structures identified in the morphologic analysis, to reconstruct the stratigraphy, and to collect rock samples. ${ }^{14} \mathrm{C}$ and U-Th desequilibrium dates of some lava domes, lava flows, and pyroclastic deposits intersected by the successive structures were performed to constrain the age of the flank collapse events. U-Th dates are obtained from $\left({ }^{238} \mathrm{U} /{ }^{232} \mathrm{Th}\right)-$ $\left({ }^{230} \mathrm{Th} /{ }^{232} \mathrm{Th}\right)$ isochrons on mineral separates and whole rocks using an analytical method described by Villemant and Fléhoc [1989].

\section{Submarine Debris Avalanche Deposits \\ 4.1. Sea Bottom Characteristics}

[13] The swath bathymetry of the studied area is presented in Figure 3. The western flank of Martinique is characterized by numerous canyons and incised steep slopes contrasting with the flat seafloor of the Grenada Basin. We identified three deposits that we interpreted as debris avalanche deposits. They extend from the coastline to the floor of the basin via well defined flat-bottomed chutes. They also display in some parts clear morphological fronts. 


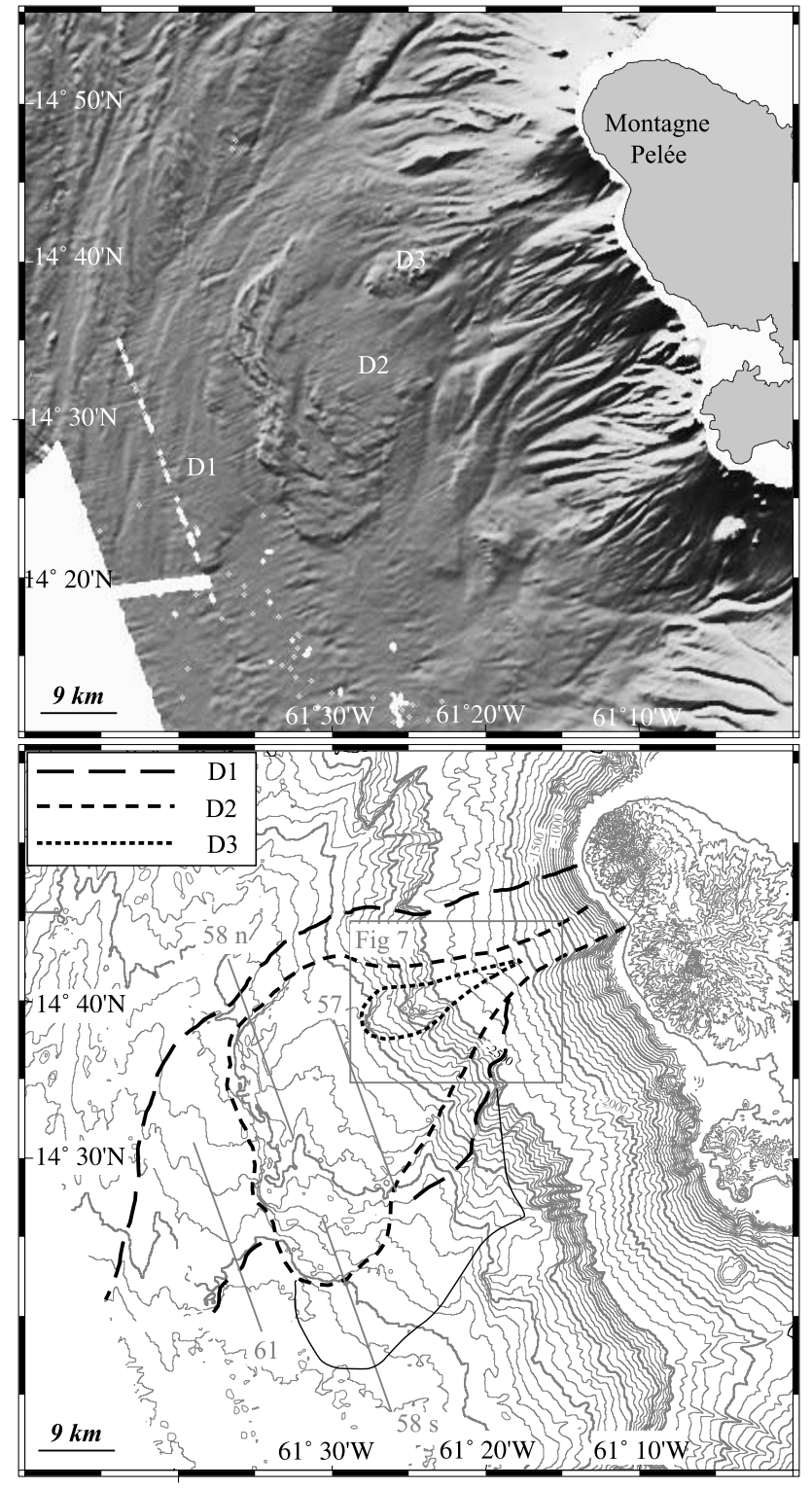

Figure 3. Swath bathymetry collected during the Aguadomar cruise southwest of Martinique island; (top) shaded image of bathymetry illuminated from $\mathrm{N} 320^{\circ}$; (bottom) bathymetry and topography data. Contour interval is $100 \mathrm{~m}$ down to $2500 \mathrm{~m}$ below sea level and $20 \mathrm{~m}$ below that. The dashed lines show the limits of the three debris avalanche deposits D1, D2, and D3 deduced from the joint analysis of the whole marine dataset. South of the debris avalanche deposits, the thin line shows the limit of the area displaying facies $3 \mathrm{~d}$ on $3.5 \mathrm{kHz}$ data (see Figure $5 \mathrm{a}$ ) and a bevel of chaotic unit on seismic reflection profiles (see Figure 9). The straight lines indicate the location of $3.5 \mathrm{kHz}$ and seismic profiles shown on Figures 6-10.

[14] Backscatter values depend on the absorption efficiency of the seafloor but also on the incidence of the beam relatively to the local slope. Five types of acoustic facies may be distinguished using a combination of backscatter intensity and pattern (Figure 4). Facies 1 corresponds to high backscatter (darkest areas) and is present on the slopes of the island and at the front of the deposits. It also underlines canyons. Facies 2 is characterized by a speckled pattern typical of chaotic deposits as debris avalanche deposits [Moore et al., 1989; Watts and Masson, 1995] and corresponds to irregular hummocky terrains. High reflectivity patches indicate the presence of blocks. They are the result both of contrasting acoustic responses of the lava blocks and the fine products surrounding them and of the angular shapes of the blocks which provide facing slopes relative to the beam geometry. Facies 3 is defined by an intermediate backscatter value and is observed on the

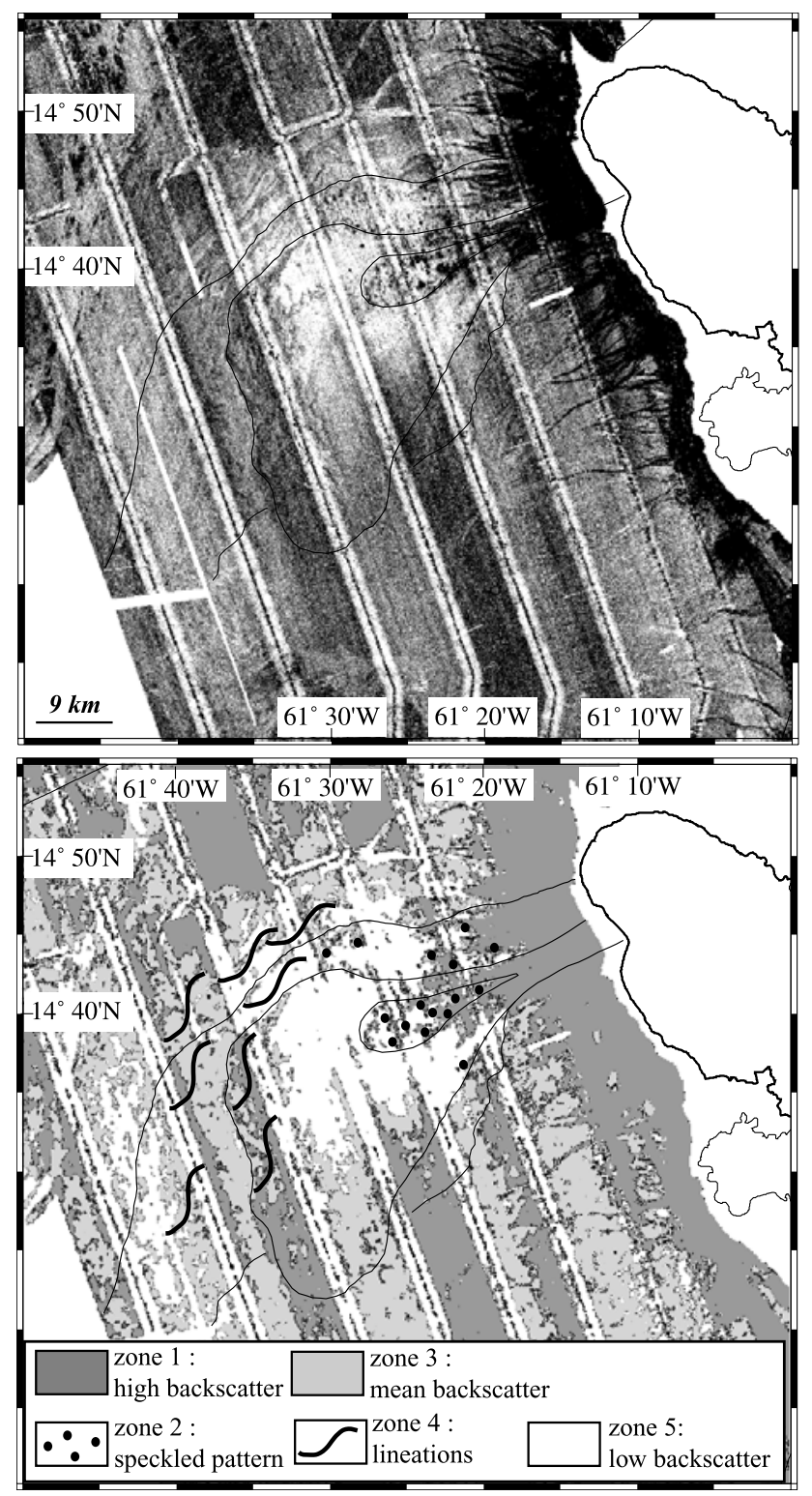

Figure 4. (top) Backscatter image of the debris avalanche deposits off Martinique (same area as in Figure 3). Backscatter level decreases from black to white. Linear white and black areas correspond to the location of ship tracks. Thin black lines are the limits of the three debris avalanche deposits. (bottom) Interpretative map of backscatter data. Five acoustic facies corresponding to different patterns and backscatter levels are identified and detailed in text. 

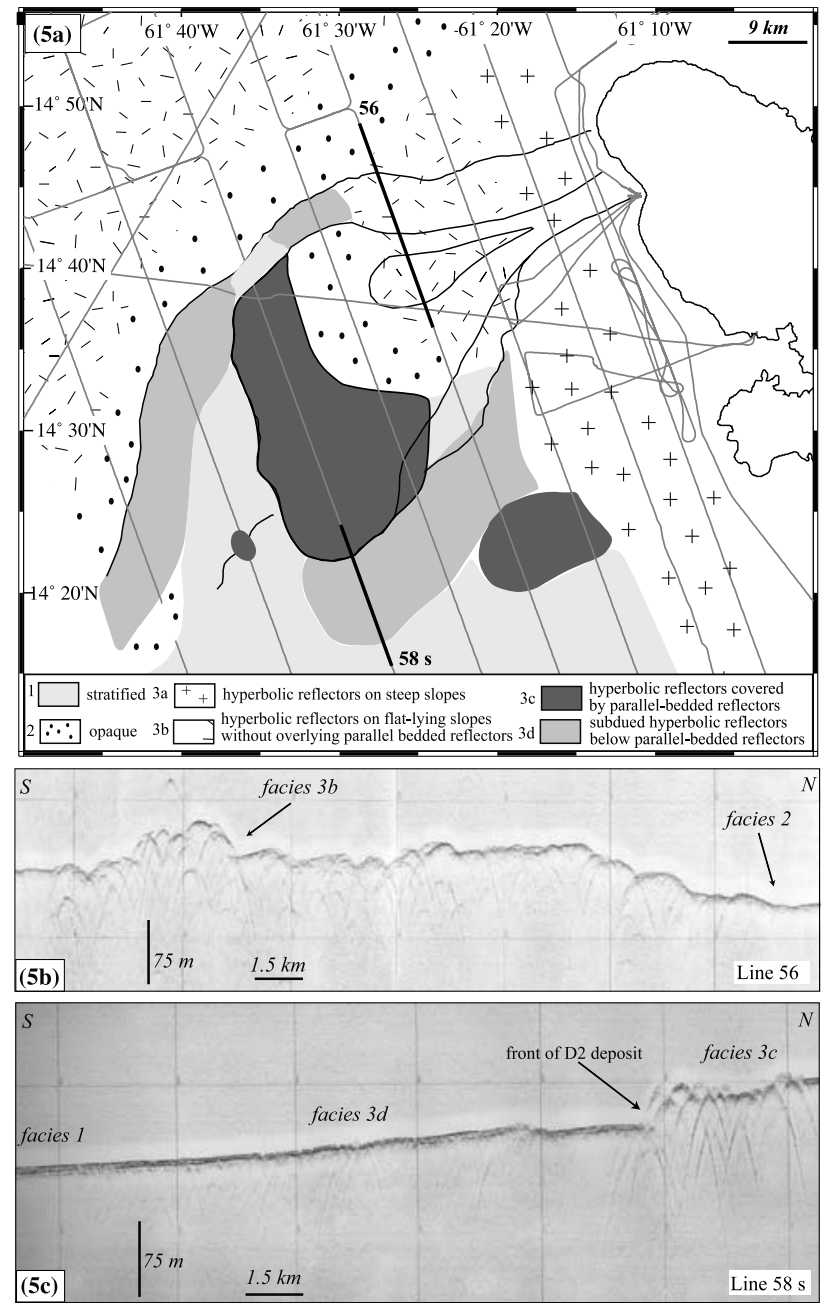

Figure 5. (a) Map of acoustic facies based on $3.5 \mathrm{kHz}$ echo sounder profiles. Ship tracks are shown with grey lines. Black lines indicate the limits of the three debris avalanche deposits. The large hyperbolic reflections zone in the northwest part of the map corresponds to debris avalanche deposits originated from the southern part of Dominica island [Deplus et al., 2001]. The lines labeled 56 and $58 \mathrm{~s}$ are $3.5 \mathrm{kHz}$ profiles shown on Figures $5 \mathrm{~b}$ and $5 \mathrm{c}$, respectively. (b) $3.5 \mathrm{kHz}$ profile 56 crossing the southern edge of deposits D1 and D2. Opaque facies (facies 2) is present outside the deposit. (c) The $3.5 \mathrm{kHz}$ profile $58 \mathrm{~s}$ crossing the southern edge of deposit D2. Debris avalanche deposits are identified by hyperbolic facies on $3.5 \mathrm{kHz}$ data and a morphological front (30 m high). Outside the deposit, flat-lying reflectors correspond to the sedimentary layers of the Grenada Basin.

floor of the Grenada Basin outside the debris avalanche deposits. It corresponds to the sediments of the basin [Masson et al., 1992]. Facies 4 is characterized by undulated lineations of relatively high backscatter and mainly corresponds to the front of the chaotic deposits. Facies 5, with very low backscatter, is generally interpreted as finegrained sediments on flat areas [Masson et al., 1992].

[15] From the $3.5 \mathrm{kHz}$ echo sounder profiles, three main acoustic facies can be identified according to the echo character and the geometry of reflectors: stratified, opaque, and hyperbolic (Figure 5a). Facies 1, characterized by parallel reflectors, indicates the presence of a layered sedimentary seafloor. Facies 2 displays a strong echo without penetration. It is observed on the floor of the chutes (Figure 5b) and may correspond to coarse-grained deposits [Pratson and Laine, 1989]. The third facies displays a chaotic texture characterized by hyperbolic reflections (Figure 5c). It is found on steep submarine slopes (facies 3a) of the islands in areas where numerous canyons lead to an important roughness of the topography. It is also observed in flat-lying areas (facies $3 b-3 c$ ) indicating the presence of rough and irregular seafloor surfaces. Such hyperbolic signatures on a flat-lying area have been interpreted by [Lipman et al., 1988; Watts and Masson, 1995; Urgeles et al., 1997] as evidence for submarine debris avalanche deposits. Such deposits can be covered by a thin sedimentary layer (facies 3b) or not (facies 3c). An intermediate facies (facies 3d) with weakly defined hyperbolic reflections below subhorizontal parallel reflectors is observed in the areas lying between the front of the debris avalanche deposits and the sediments of the basin.

[16] On seismic reflection profiles, two main acoustic units were identified (Figure 6). The first unit consists of continuous subhorizontal reflectors corresponding to the parallel bedded sedimentary layers of the Grenada Basin. The second unit displays chaotic reflectors with large energy diffraction. Its thickness is $\sim 0.2 \mathrm{~s}$ two-way travel time (twt). Previously, Deplus et al. [2001] showed that such a thick chaotic unit indicates the presence of debris avalanche deposits. The thickness of this unit is thereafter

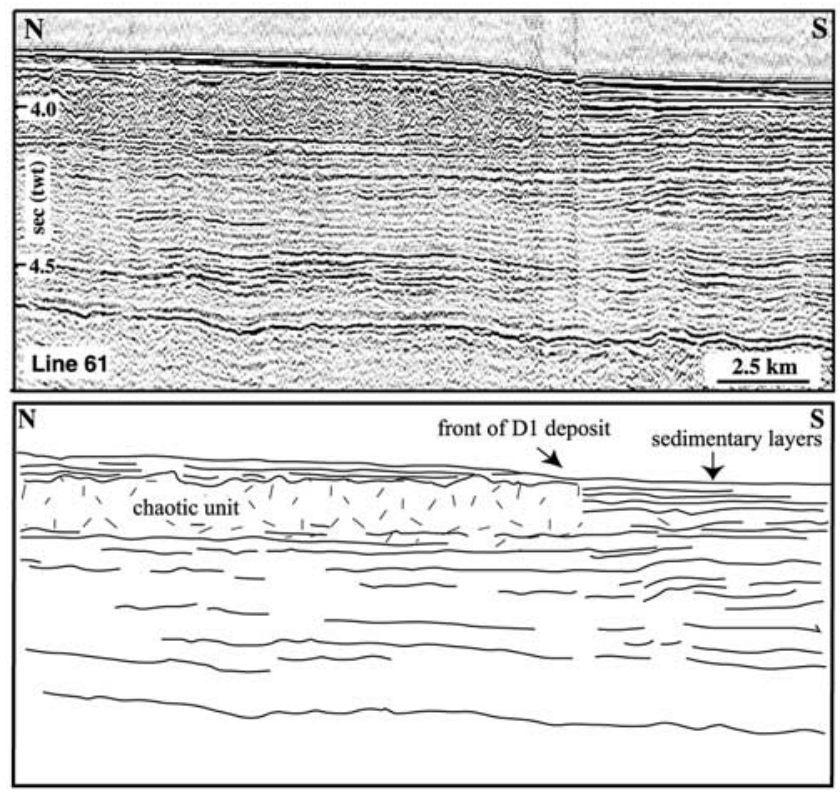

Figure 6. Air gun seismic profile 61 (location on Figure 3) crossing the southern limit of deposit D1, with interpretative section. Debris avalanche deposits are identified by an incoherent/chaotic unit and contrast with subhorizontal and well-bedded sedimentary layers corresponding to normal sedimentation in the Grenada Basin; twt is two-way travel time. 


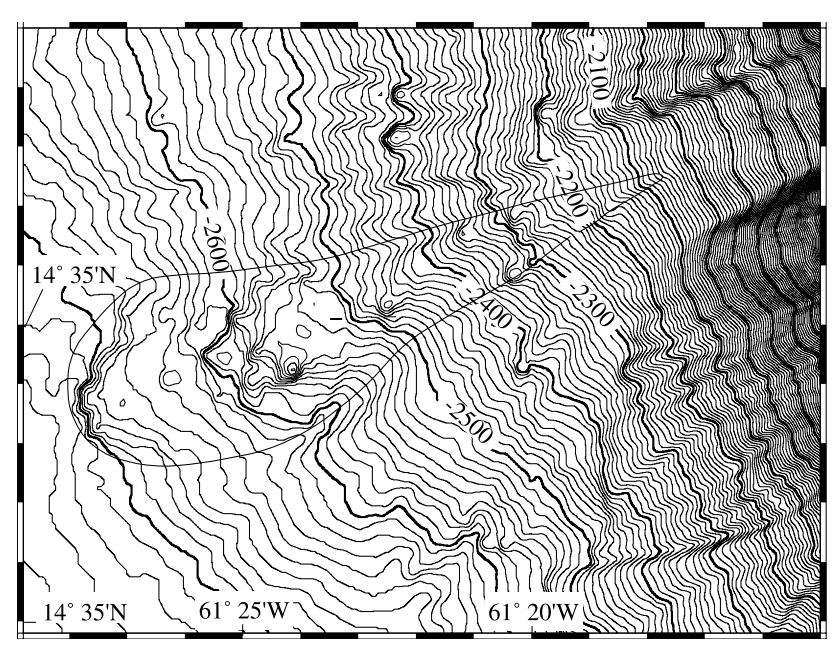

Figure 7. Detailed swath bathymetry of hummocky morphology of the debris avalanche deposit D3. Contour interval is $10 \mathrm{~m}$.

estimated using a seismic velocity of $1800 \mathrm{~m} / \mathrm{s}$ [Urgeles et al., 1997; Collot et al., 1999].

\subsection{Identification of Three Debris Avalanche Deposits}

[17] Three debris avalanche deposits (called D1, D2, and D3 deposits, respectively) were identified on the western submarine flank of Montagne Pelée and extend in the Grenada Basin (Figure 3). Deposit D2 is the most clearly defined. It displays a clear morphological front and extends from a chute well marked in the topography of the submarine flanks of Montagne Pelée. A much smaller deposit, D3, clearly overlies deposit D2. A larger one, D1, lies below it.

[18] The small deposit D3 has a typical lobate shape (Figure 3) and is located between isobaths 2300 and 2700 $\mathrm{m}$. It covers an area of $60 \mathrm{~km}^{2}$ and presents a typical hummocky morphology. Megablocks, $100-500 \mathrm{~m}$ in diameter and 10-40 m high (Figure 7), are concentrated in the central part of the deposit. They display a characteristic speckled pattern on the backscatter data and hyperbolic reflections on the $3.5 \mathrm{kHz}$ profiles (Figure $5 \mathrm{a}$, facies $3 \mathrm{~b}$ ). The lack of sedimentary cover on the blocks attests of the recent age of this deposit.

[19] Deposit D2 has a larger extent (Figure 3). It extends up to $50 \mathrm{~km}$ from the coastline and covers an area of 700 $\mathrm{km}^{2}$ between isobaths 2200 and $2900 \mathrm{~m}$. It extends down to the flat Grenada Basin (slopes $\sim 2^{\circ}$ ) and displays a distinctive topographic front between isobaths 2800 and $2900 \mathrm{~m}$. The front is generally $10-20 \mathrm{~m}$ high but can reach locally $35 \mathrm{~m}$ (Figure $5 \mathrm{c}$ ). The morphology of deposit D2 is relatively smooth in its northeastern part, but it becomes rough in its western and southern parts with ridges up to 10 $\mathrm{m}$ high and parallel to the front (Figure 3). However, as observed on the aerial nonvolcanic Blackhawk landslide in California [Johnson, 1978], such ridges could also correspond to overlapped structures resulting from an abrupt deceleration of the front of the flow, propagating rearward, in an area where the slope is very low. There is evidence of active erosion of the deposit because it is incised by deep canyons. Seismic reflection profiles over deposit D2 show the chaotic unit characteristic of debris avalanche deposits (thickness of $\sim 150-200 \mathrm{~m}$ ). Over the southern part of deposit D2, hyperbolic reflections are very well defined on the $3.5 \mathrm{kHz}$ profiles (facies $3 \mathrm{c}$, Figures $5 \mathrm{a}$ and $5 \mathrm{~b}$ ). They are covered by parallel bedded reflectors characteristic of layered fine-grained sediments with an estimated total thickness of $\sim 4 \mathrm{~m}$. The central part of deposit D2, where the morphology is smooth, displays a contrasting signature in $3.5 \mathrm{kHz}$ profiles, backscatter images and seismic profiles. In this part, the $3.5 \mathrm{kHz}$ profiles display an opaque facies without hyperbolae (facies 2, Figure 5a) and a very low backscatter signature (zone 5, Figure 4). These two types of facies are usually not correlated [Masson et al., 1992]. On the seismic profiles (Figure 8), continuous subhorizontal reflectors overly the chaotic unit. They correspond to a thick and well-bedded sedimentary layer (thickness of $0.08 \mathrm{~s} \mathrm{twt}$, i.e., $\sim 70 \mathrm{~m}$, using a velocity of $1800 \mathrm{~m} / \mathrm{s}$ ) which has an abnormal thickness in comparison with the other parts of the deposit. Last, south of the morphological front, few subbottom hyperbolae (facies $3 \mathrm{~d}$ ) are observed on $3.5 \mathrm{kHz}$ profiles (Figure 5a). They are correlated with a thin chaotic unit identified on the seismic reflection profiles (Figure 9).

[20] Deposit D1 extends up to $60 \mathrm{~km}$ from the coastline and is mainly covered by deposit D2. Its morphology is not as clear as for the other deposits, although a well-marked topographic front can be identified in its southwestern part (Figure 3). This front correlates with the extension of the chaotic unit seen on seismic profile 61 (Figure 6). The southeastern limit is deduced from a north-south discontinuity at $61^{\circ} 20^{\prime} \mathrm{W}$ that crosscut the canyons draining the southwest submarine flanks of Martinique Island. Some of the main canyons have dug the deposit again. Several points

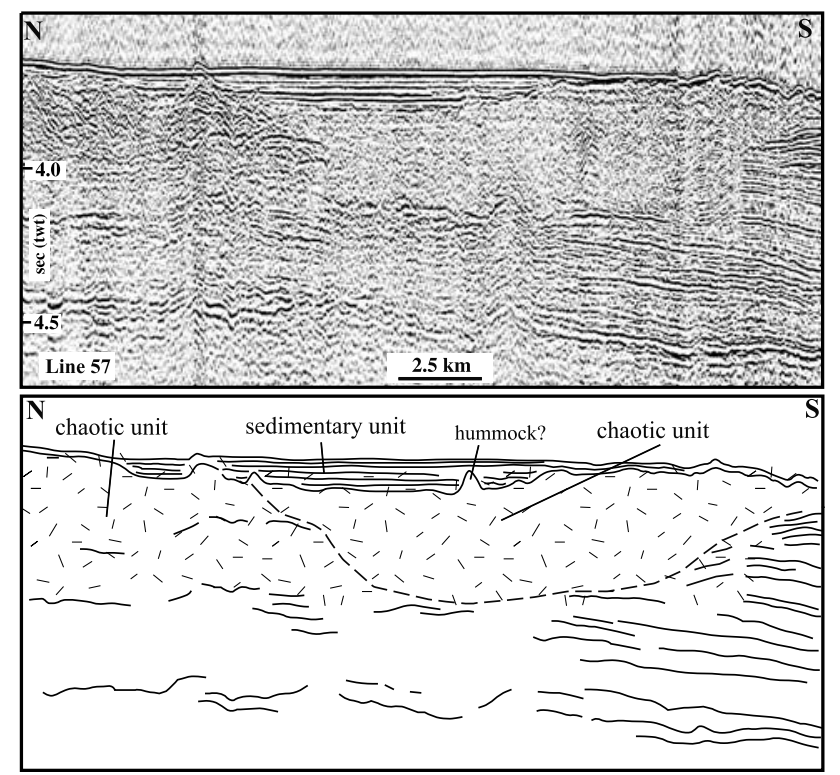

Figure 8. Air gun seismic profile 57 (location on Figure 3) crossing the middle part of deposit D2 and interpretative section. The seismic profile shows an important thickness of well-bedded sedimentary layers covering deposit D2. The thickness is up to 0.08 twt and corresponds to $\sim 70 \mathrm{~m}$ (using a velocity of $1800 \mathrm{~m} / \mathrm{s}$ ). The area also corresponds to very low backscatter ("zone 5" on Figure 4) and to opaque facies on $3.5 \mathrm{kHz}$ profiles (facies 2 on Figure $5 \mathrm{a}$ ). 

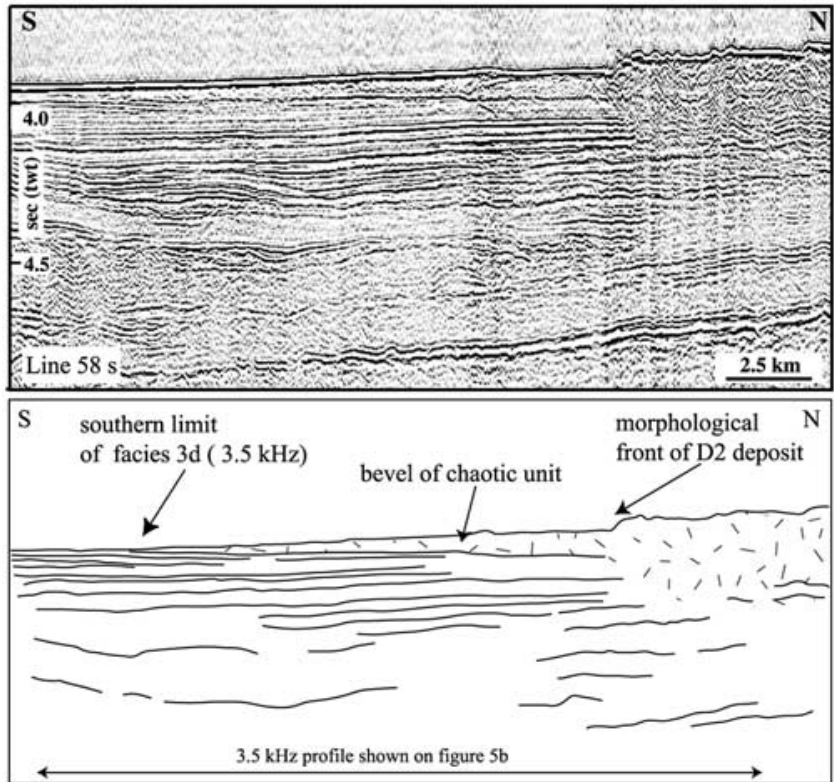

Figure 9. Air gun seismic profile 58s (location on Figure 3 ) crossing the southern edge of deposit D2 with interpretative section. The morphological front underlines the southern limit of the thick chaotic unit. Southward, a bevel with chaotic signature thins progressively and ends at the southern limit of facies $3 \mathrm{~d}$ on $3.5 \mathrm{kHz}$ profiles.

permit to propose a northern limit for this deposit north of deposit D2 (Figure 3): (1) On the seismic profile 58n (Figure 10), north of the morphological front of deposit D2, another morphological front can be interpreted as the limit of deposit D1, and the sedimentary cover has a greater thickness, indicating that this deposit is significantly older than deposit D2; (2) north of deposit D2, few megablocks appear on the submarine flanks of the island, between isobaths 2000 and $2500 \mathrm{~m}$ (Figures 3 and 4); and (3) the regular morphology of the submarine flank in the same area contrasts with the morphology to the north with numerous and deep radial canyons. The thickness of the sedimentary cover above D1 masks its chaotic structure on $3.5 \mathrm{kHz}$ profiles (lack of hyperbolic reflections) leading to a smooth morphology. Moreover, the thickness of the chaotic unit displayed by seismic profiles is greater south of the topographic front of deposit D2 (0.5 and $0.2 \mathrm{~s}(\mathrm{twt})$, respectively, on Figure 10). We interpret this large thickness as resulting from the superimposition of deposits D1 and D2. Deposit D1 has a total extent of $\sim 1100 \mathrm{~km}^{2}$.

\subsection{Existence of Chutes on the Submarine Flank of Montagne Pelée}

[21] Bathymetric data clearly show that deposit D2 extends from a chute, well marked in the topography of the submarine flank of Montagne Pelée (Figure 3). The chute, striking $\mathrm{N} 240^{\circ}$, is $13 \mathrm{~km}$ long and $4 \mathrm{~km}$ wide. It extends from the coastline down to isobath $2200 \mathrm{~m}$ covering an area of $50 \mathrm{~km}^{2}$. It is bound by two well-marked rims with different height. The northern rim is 10 to $60 \mathrm{~m}$ high, whereas the southern rim increases from 150 to $350 \mathrm{~m}$ in height between isobath $1700 \mathrm{~m}$ and the coastline. The floor of the chute is relatively smooth in comparison with the surrounding submarine flanks cut by narrow and deep canyons. It shows high backscatter (Figure 4). The lack of erosional canyons within the chute indicates a young age. Inside the upper part of the chute, an elongated depression $3.5 \times 0.5 \mathrm{~km}$ extends from the coastline to isobath $1200 \mathrm{~m}$ (Figures 2 and 3) with a $\mathrm{N} 40^{\circ}$ strike, oblique to the direction of the main chute. Its lower end abuts against the southern rim of the main chute. The depression is 30 to $40 \mathrm{~m}$ deep in the continuity of the Rivière Blanche valley. We interpret it as a younger narrower chute related to deposit D3.

\section{On-Land Geological Data}

\subsection{Identification of Morphological Discontinuities}

[22] Geological and morphological data obtained on the basis of field observations, digital topography, and aerial photograph interpretations allow us to identify five topographic discontinuities on the western flank of Montagne Pelée (Figure 11). Two of them were recognized by Vincent et al. [1989] (discontinuities 1 and 2) and interpreted as the rims of the same flank collapse structure, as mentioned in section 2 .

[23] The first discontinuity is a 100 to $150 \mathrm{~m}$ high northwest facing scarp on the left bank of Rivière Roxélane that extends from St. Pierre to an elevation of $600 \mathrm{~m}$. Its upper part disappears under the recent products of Montagne Pelée. It is irregular and dissected by several lateral deep valleys. Discontinuity 1 intersects old lava domes and lava flows (Morne Calebasse, Morne Essentes). To the northwest the regular topography of the recent pyroclastic deposits of Montagne Pelée contrasts with the irregular morphology of the southeastern older deposits, most of
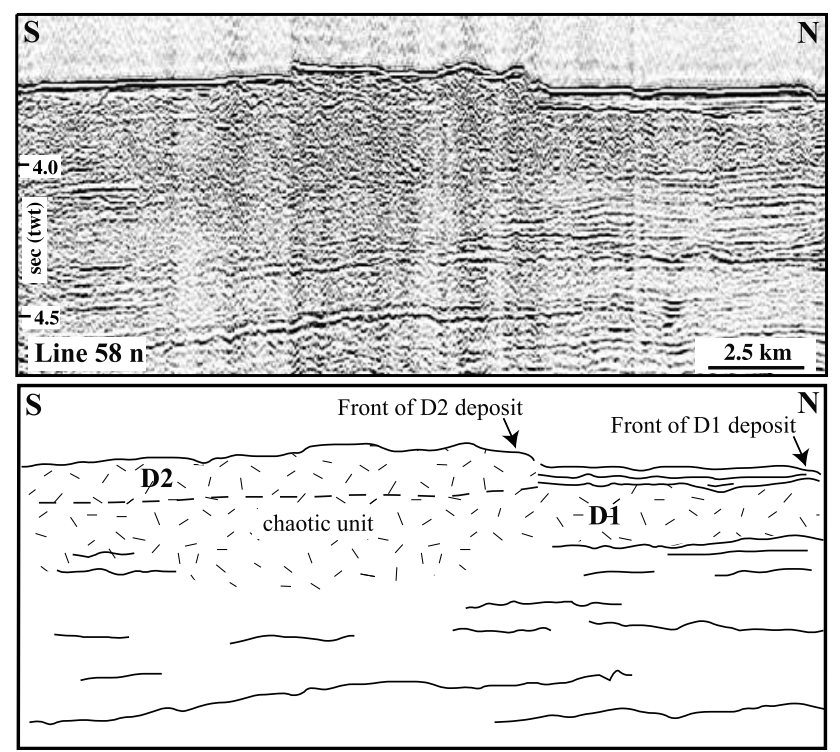

Figure 10. Air gun seismic profile 58n (location on Figure 3) crossing the northern parts of deposits D1 and D2, with interpretative section. A sedimentary cover with significant thickness is only present on deposit D1, attesting of its older age. The chaotic unit is thicker when both deposits are superimposed. 


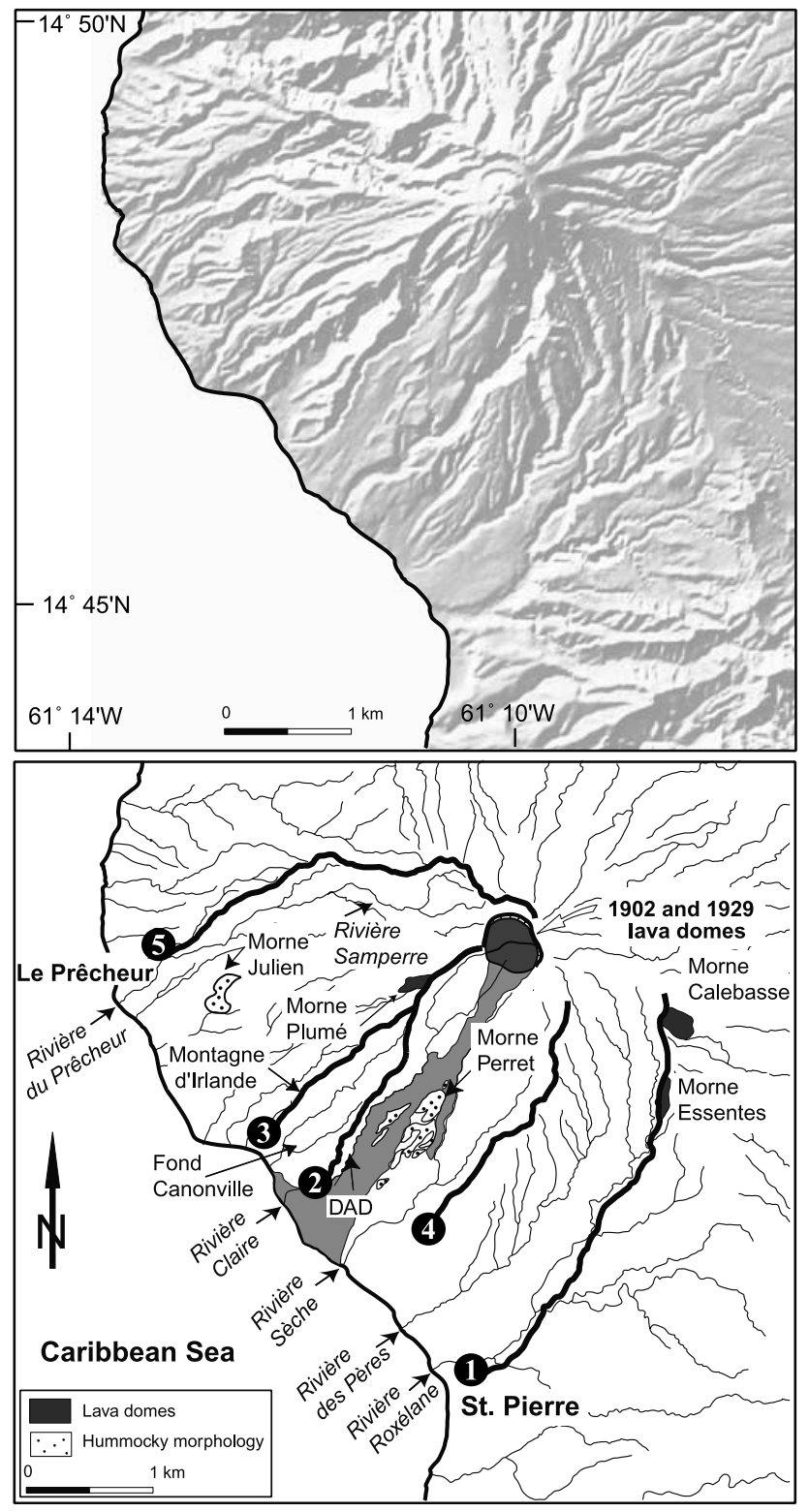

Figure 11. (top) Shaded image of topography illuminated from $\mathrm{N} 320^{\circ}$ and produced using the $50 \mathrm{~m}$ DTM of Martinique island, provided by IGN, France. (bottom) Interpretative map showing the hydrographic system of Montagne Pelée and major topographic discontinuities. Debris avalanche deposits with hummocky morphology are represented by a dotted pattern. Dark grey areas are lava domes. Grey area indicates block-and-ash-flow deposits of the 1902 and 1929 eruptions filling the Rivière Blanche valley.

them belonging to the Pitons du Carbet volcano. On both sides of the scarp, the hydrographic system has developed in divergent directions: $\mathrm{N} 240^{\circ}$ in the northwestern area (Rivière Roxélane, Rivière des Pères) and $\mathrm{N} 30^{\circ}$ to $\mathrm{N} 130^{\circ}$ in the southeastern part, with different flow directions (west-east or northwest-southeast in the upper part; east-west or northeast-southwest in the lower part).

[24] The second discontinuity is a continuous cliff, facing southeast, on the right bank of Rivière Claire, 100-150 m high, with a great difference of altitude on both sides of the valley (Figure 12a). It is particularly well marked in the upper part of the volcano where it forms a $300 \mathrm{~m}$ high regular and weakly eroded cliff that cuts the Morne Plumé lava flows. In the summit area, it disappears under the recent lava domes. The recent block-and-ash-flow deposits of the 1902 and 1929 eruptions were channeled by this rim into the Rivière Blanche valley.

[25] To the northwest, another morphological discontinuity (discontinuity 3 in Figure 11), facing southeast, is identified along the crest of Montagne d'Irlande on the right bank of the Fond Canonville valley. In the upper part of the volcano it is cut by discontinuity 2 and in the lower part by small valleys.

[26] A fourth morphological discontinuity is formed by a cliff facing northwest on the left bank of Rivière Sèche (Figures 11 and 12a). In the upper part of the valley it disappears under the recent products. The rim is clearly defined by the hydrographic system. The valleys on the southwestern flank of the volcano generally display a $\mathrm{N} 240^{\circ}$ direction (Figure 11), consistent with the orientation of the horseshoe-shaped structure identified by Vincent et al. [1989] in which the new cone is edified. To the southeastern part of the crest, valleys have different directions that vary from $\mathrm{N} 160^{\circ}$ to $\mathrm{N} 180^{\circ}$. They are tributaries of Rivière des Pères oriented $\mathrm{N} 240^{\circ}$ and have their source along this crest. The existence of perched valleys indicates that their upper part has been cut by the discontinuity. We assume that this cliff has a structural origin that has locally modified the hydrographic system. Different lithologies were recognized on both side of Rivière Sèche valley. On the left bank, thick scoria flows belonging to the second phase of building of the volcano $(25,000 \pm 1040$ years B.P. [Westercamp and Traineau, 1983a, 1983b] are covered in the upper part of the cliff by more recent products. On the right bank, these old scoria flow deposits are absent and all pyroclastic deposits are more recent with a maximum ${ }^{14} \mathrm{C}$ age of $3740 \pm 120$ years B.P. [Westercamp and Traineau, 1983b]. Moreover, the left side of the valley is regular and not dissected by new valleys; it is higher and steeper that the right side.

[27] A fifth curved morphological discontinuity has been recognized facing south-southwest on the right bank of Le Prêcheur and Samperre valleys. It extends from the coastline to the summit area with heights of 150 to $500 \mathrm{~m}$. This scarp partially cuts the Mont Conil edifice. As for the previous features, main river directions on both sides of the upper part of the scarp are different (Figure 11): southnorth to the north and east-west to the south. This scarp is very irregular and cut by several valleys. Some landslides have modified its original outline. These features suggest that these five discontinuities can be interpreted as rims of several flank collapse structures.

\subsection{Debris Avalanches Deposits}

[28] Debris avalanche deposits and hummocky morphologies have also been identified on different areas on the western flank of Montagne Pelée (Figure 11). In the lower part of the Rivière Claire valley, outcrop coarse-grained deposits containing a yellowish matrix, blocks with jigsaw cracks structure and stretched hydrothermalized zones (Fig- 
(a)
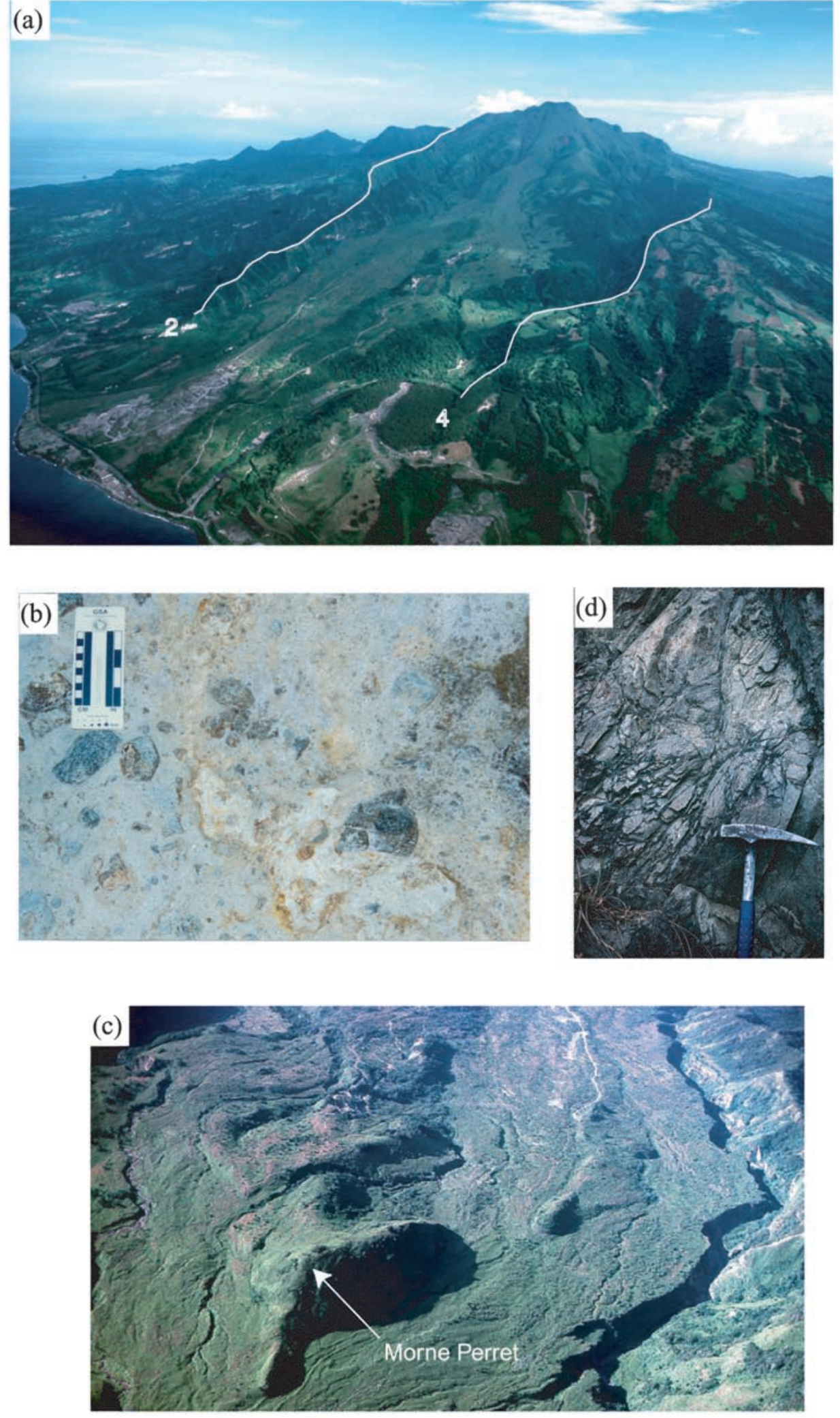

Figure 12. (a) View of the southwestern flank of Montagne Pelée showing the structural discontinuities 2 and 4. (b) Debris avalanche deposits in the lower part of Rivière Claire showing a yellowish matrix, blocks with jigsaw cracks structure and stretched hydrothermalized zones. (c) Hummocky morphology on the southwestern flank of Montagne Pelée between discontinuities 2 and 4 viewed from the summit of the volcano. (d) Jigsaw crack structures on massive lava of the Morne Julien megablock. 


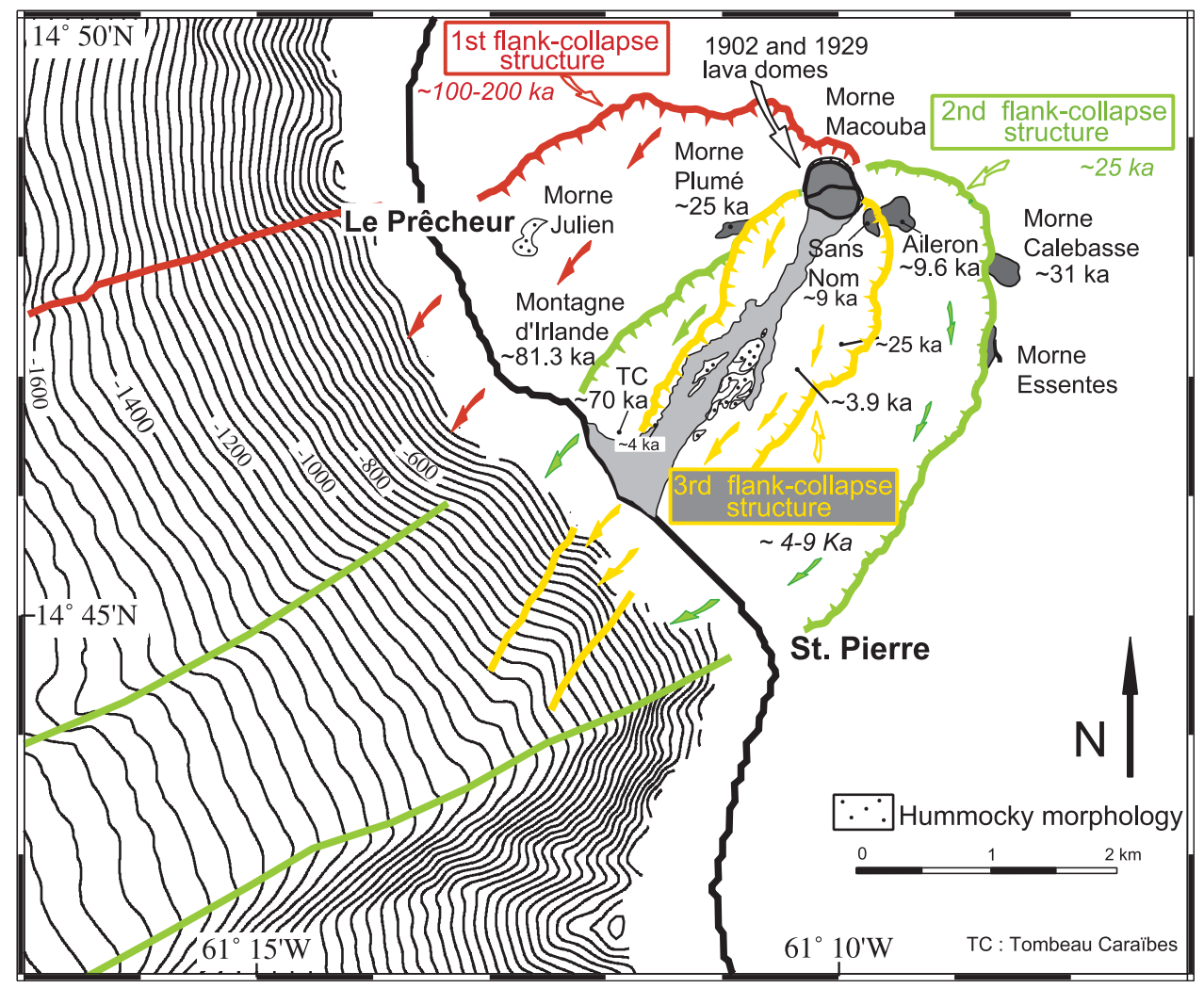

Figure 13. Map showing flank collapse spatial relations between the submarine chutes and the horseshoe-shaped structures identified on Montagne Pelée volcano. Radiometric age dates discussed in the paper are also reported. See Figure 11 for legends of mapped units.

ure 12b). We also recognized hydrothermalized blocks with a thick rust patina and silicified clasts. On the right bank of rivière Claire, these deposits are in vertical contact with older pumice flow deposits. We interpret them as formed by a debris avalanche which eroded older block-and-ash-flow deposits.

[29] Several hills are present on the lower flank of the volcano between the two valleys of Rivière Claire and Rivière Sèche, at an elevation up to $450 \mathrm{~m}$ (Figures 11 and $12 \mathrm{c})$. They are surrounded by recent pyroclastic flow deposits and covered by fallout deposits several tens of meters thick. The larger hill is $500 \mathrm{~m}$ long and $100-150 \mathrm{~m}$ high. All these hills are elongated in a $\mathrm{N} 240^{\circ}$ direction parallel to the morphological discontinuities. Hills in the lower part of the volcano overlap each other. Their location excludes that they could represent lateral vents of the volcano, because in such a composite volcano, all the eruptive activity is located in the summit area. These hills can be interpreted as megablocks associated to a flank collapse event.

[30] On the western flank of the volcano, Morne Julien hill culminates at $386 \mathrm{~m}$ above sea level (Figure 11). It was considered as an old volcanic center contemporary to the Mont Conil emplacement and surrounded by more recent pyroclastic products of Montagne Pelée [Vincent et al., 1989]. However, most of Morne Julien is constituted by massive lavas with well-developed jigsaw crack structures. Locally, the rocks are entirely shattered (Figure 12d). The petrographic characteristics of these lavas are identical to those of Mont Conil lavas. The morphology of Morne Julien is the result of several overlapping hills, some of them being 350-400 $\mathrm{m}$ long. Thus Morne Julien can be interpreted as a series of overlapped megablocks emplaced by debris avalanches.

\section{Identification of Three Flank Collapse Events on the Southwestern Flank of Montagne Pelée: Relations Between On-Land and Offshore Data 6.1. First Flank Collapse Event (Le Prêcheur Flank Collapse)}

[31] The northern limit of deposit D1 (Figures 13 and 14) can be correlated on land with the curved scarp on the right side of Rivière du Prêcheur (discontinuity 5 on Figure 11) which can be interpreted as the northern rim of an old horseshoe-shaped structure (called structure 1). The small scarp offshore between the coastline and isobath $500 \mathrm{~m}$, in the continuity of this rim, can be interpreted either as the continuity of the structure or as the boundary of a chute eroded by the passage of the debris avalanche (Figures 3 and 13). The southern rim of the structure is not identified and probably masked by the more recent flank collapse events. We propose that it can be located near the southern rim of structure 2 (i.e., discontinuity 1 ) in relation with the boundary of the southern limit of deposit D1. In this case, the high southern rim of the main chute related to deposit D2 would be the result of both flank collapse events 1 and 2 . 


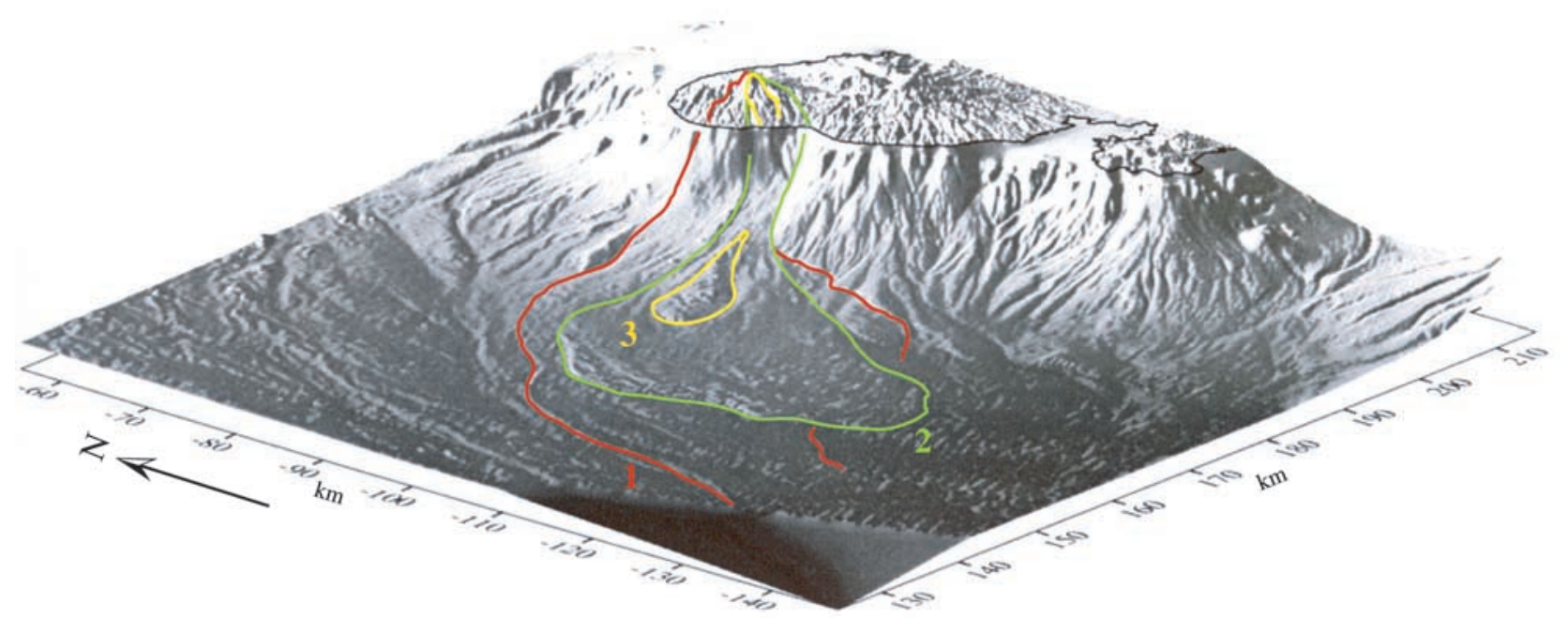

Figure 14. Three-dimensional representation of combined bathymetry and topography data of Martinique island and submarine slopes. The image is constructed using Aguadomar swath bathymetry offshore and IGN DTM onshore. The black line corresponds to sea level. The data were projected using Mercator projection and the axis are labeled in kilometers (reference latitude $15^{\circ} 30^{\prime} \mathrm{N}$, origin $15^{\circ} 30^{\prime} \mathrm{N}$, $\left.63^{\circ} \mathrm{W}\right)$. The image is viewed from the southwest $\left(\mathrm{N} 230^{\circ}\right)$ and is illuminated from $\mathrm{N} 330^{\circ}$. Vertical exaggeration is 2.5 . The color lines show the limits of the three submarine deposits and their correlation with the aerial horseshoe-shaped structures (red indicates flank collapse 1; green indicates flank collapse 2; and yellow indicates flank collapse 3).

\subsection{Second Flank Collapse Event (St. Pierre Flank Collapse)}

[32] The southern limit of the elongated chute identified on the submarine flank of Montagne Pelée and related to deposit D2 (dark grey lines on Figure 13) is in perfect alignment with the southern rim of the horseshoe-shaped structure proposed by [Vincent et al., 1989] (discontinuity 1 on Figure 11) in front of St. Pierre (Figure 13). On the contrary, the northern limit of the channel does not correspond to discontinuity 2 initially proposed by Vincent et al. [1989] as the northern rim of the flank collapse structure. It is offset to the north by $\sim 1 \mathrm{~km}$. However, it is aligned with the Montagne d'Irlande ridge (discontinuity 3). In addition, the positive SP anomaly recognized by Zlotnicki et al. [1998] extends outside discontinuity 2 . The northern limit coincides more accurately with the ridge of Montagne d'Irlande (discontinuity 3 ). Thus we propose that structure 2 corresponding to the second flank collapse event is delimited to the south by discontinuity 1 and to the north by the ridge of Montagne d'Irlande, (Figure 13). The distribution of the hydrographic system also underlines this second structure as most of the valleys are radial outside the depression, whereas they have a $\mathrm{N} 180^{\circ}$ to $\mathrm{N} 240^{\circ}$ direction inside the depression (Figure 11). The new geometry proposed for structure 2 might also explain the concavity of the coastline between the ridge of Montagne d'Irlande and St. Pierre that indicates that the flank collapse also affected the submarine flank of the volcanic edifice.

[33] The close relations between deposit D2, the submarine chute, and structure 2 suggest that they are related to the same flank collapse event (Figures 13 and 14). The chute thus represents either the submarine continuity of the rims of the horseshoe-shaped structure or the result of flow erosion. Structure 2 is $6 \mathrm{~km}$ long on land, and the chute is
$13 \mathrm{~km}$ long on the submarine flank of the volcano. Similar features are observed at Stromboli volcano where the aerial remnants of the "Sciara del Fuoco" flank collapse structure are prolonged by a submarine chute several kilometers long [Kokelaar and Romagnoli, 1995]. In the case of Montagne Pelée the length of the chute and its narrowness suggest strongly an erosional origin associated with emplacement of debris avalanche. Only a small part of the submarine flank (down to a depth $<200 \mathrm{~m}$ ) which corresponds to the concave shape of the coast, can be associated to the flank collapse structure itself. The proposed horseshoe-shaped structure would thus be $6.5 \times 4 \mathrm{~km}$ in size (of which 0.5 $\mathrm{km} \times 4 \mathrm{~km}$ offshore) and the corresponding missing volume is estimated at $\sim 13 \mathrm{~km}^{3}$ on the basis of a mean thickness of $500 \mathrm{~m}$ for the sliding mass. The important height (up to $300 \mathrm{~m}$ ) of the southern rim of the chute nearshore (Figure 11) can be accounted by erosion of debris avalanches 1 and 2 and the proximity of the older Pitons du Carbet volcano.

\subsection{Third Flank Collapse Event (Rivière Sèche Flank Collapse)}

[34] The most recent deposit D3 can be correlated with a smaller horseshoe-shaped structure (structure 3) located within structure 2. Its northern and southern rims are identified as the scarps on the right bank of Rivière Claire (discontinuity 2) and on the left bank of Rivière Sèche (discontinuity 4), respectively (Figures 13 and 14). Its size is $1.5 \times 4 \mathrm{~km}$ and the missing volume can be estimated at $\sim 2 \mathrm{~km}^{3}$ on the basis of a mean thickness of 300-400 $\mathrm{m}$ for the sliding mass. The volcanic products belonging to the growth of the present cone cover the upper part of this structure. The different hills identified on land inside structure 3 , the debris avalanche deposits in the lower part 
of the Rivière Claire valley and submarine deposit D3 with hummocky morphology are related to structure 3 and belong to the same flank collapse event. The total volume of the deposit (offshore $\sim 1.6 \mathrm{~km}^{3}$ and on land $\sim 0.1 \mathrm{~km}^{3}$ ), around $2 \mathrm{~km}^{3}$, is consistent with the size of structure 3 and the estimated collapsed volume. The small chute observed offshore between the coastline and isobath $1300 \mathrm{~m}$ (Figure 13), 30-40 $\mathrm{m}$ deep, in the continuity of structure 3 and inside the chute related to deposit D2, can be interpreted as resulting of the submarine erosion produced by flowing of the debris avalanche. The main axis of deposit D3 (eastwest) is oblique relative to structure 3 and the corresponding chute (northeast-south west); it indicates that the debris avalanche was deviated to the north by the southern rim of the main chute related to deposit D2.

\section{Discussion}

\subsection{Age of the Flank Collapse Events}

[35] In the 1980s, numerous ages were obtained on the pyroclastic deposits of Montagne Pelée [Traineau, 1982]; most of them are reported on the volcanological map [Westercamp and Traineau, 1983b]. Though many dates exist, this study has required us to obtain new ages on deposits cut by the rim of the collapse structures, or infilling them, in order to constrain the chronology of the three flank collapse events. Ages on two lava domes, a lava flow and three block-and-ash-flow deposits were obtained by the UTh desequilibrium method. Other ages were obtained by the ${ }^{14} \mathrm{C}$ method on charcoal samples found in pumice and block-and-ash-flow deposits (Figure 13).

[36] Vincent et al. [1989] proposed a minimum age of $25,000 \pm 1040$ years B.P. for the second flank collapse event obtained on charcoal sampled in scoria flow deposits which filled the horseshoe-shaped structure. U-Th desequilibrium dating of lava domes and lava flows intersected by structure 2 or outside the structure gives ages of $37 \pm 4 \mathrm{ka}$ for the Morne Calebasse lava dome (cut by the eastern rim of the structure) and $25 \pm 1 \mathrm{ka}$ for the Morne Plumé lava flow (outside the western rim). Thus the second flank collapse event likely occurred around $25 \mathrm{ka}$. The offshore distal part of deposit D2 is covered by $\sim 4 \mathrm{~m}$ of sediments implying a sedimentation rate of $\sim 16 \mathrm{~cm} / \mathrm{kyr}$ for the last $25 \mathrm{kyr}$. Such a value is in the range of the sedimentation rates $(4-21 \mathrm{~cm} /$ kyr), deduced from coring in the Grenada Basin [Sigurdsson et al., 1980; Reid et al., 1996]. An older U-Th age of $81.3 \pm$ 5 ka was obtained on block-and-ash-flow deposits sampled in the ridge of Montagne d'Irlande. It corresponds to older deposits which fill the first horseshoe-shaped structure and are cut by structure 2 . However, a U-Th age of $75.1 \pm 3 \mathrm{ka}$ was obtained on block-and-ash-flow deposits at the base of the "Tombeau des Caraibes" cliff, inside structure 2. It is in apparent contradiction with the age of $25 \mathrm{ka}$ that we propose for structure 2. Taking into account the arguments developed before on the northern limit of the structure, it is likely that the ridge which forms the "Tombeau des Caraibes" cliff is a slide block from the second flank collapse event which came to rest inside the horseshoe-shaped structure 2. It was later cut by the younger horseshoe-shaped structure 3 .

[37] The third flank collapse event occurred after the growth of a new cone inside the second horseshoe-shaped structure. The interval of time between the two events should have been long enough to emplace a sufficiently large cone to induce a new flank collapse. U-Th desequilibrium dating provide strong constrains on the age of this event. The Aileron lava dome, located in the summit part of Montagne Pelée, intersected by the structure, was dated at $9.7 \pm 0.5 \mathrm{ka}$. The postcollapse "Sans nom" lava dome, located inside the flank collapse structure was dated at $9 \pm 1$ ka. Thus the most recent flank collapse event likely occurred around $9 \mathrm{ka}$. This young age is compatible with more recent pyroclastic products filling the structure which have a ${ }^{14} \mathrm{C}$ age of $4020 \pm 80$ years B.P. [Roobol and Smith, 1976] and with the rough morphology of the correlated submarine deposit D3 without any sedimentary cover.

[38] No dates are available for the oldest flank collapse, which destroyed a great part of the western flank of the primitive edifice of Montagne Pelée. The horseshoe-shaped structure cuts the southern part of the older Mont Conil volcano. The thickness of the sedimentary cover on the distal part of submarine deposit D1 which we interpret as correlative to this event is estimated to be less than $30 \mathrm{~m}$ thick from the seismic profiles and more than $15 \mathrm{~m}$ from 3.5 $\mathrm{kHz}$ profiles. This large thickness of sediments compared to the one observed on deposit D2 indicates a much older age ( 4-8 times larger, i.e., 100-200 ka).

\subsection{Deposit Mechanism and Estimation of the Volume of the Debris Avalanche Deposits}

[39] Previously, Deplus et al. [2001] discussed the origin of the chaotic unit observed on seismic data. We proposed that it is the result of not only direct submarine deposition of debris avalanches but also of particular transport conditions of debris avalanches in a sedimentary basin. Debris avalanches would erode the upper sedimentary layers of the basin of which large amounts can be incorporated in the flow as well as disturb lower sedimentary layers. The upper part of the chaotic unit is thus probably made up of both primary debris avalanche material and reworked sediments whereas the lower part would only consist of disturbed marine sediments (Figure 6). We propose that the bevel of diffracting material observed on seismic profiles (Figure 9) at the front of some of the deposits was emplaced by spreading of the debris avalanche. The erosional potential of the debris avalanche is compatible with the formation of the deep submarine chutes.

[40] Therefore the thickness of the chaotic unit cannot be used to estimate the volume of the primary debris avalanche materials. However, on the basis of morphological considerations such as the average height of the front of $30 \mathrm{~m}$ (maximum $35 \mathrm{~m}$ ) and extension of each deposit, we obtain estimated volumes for each deposit : $\sim 30 \mathrm{~km}^{3}$ for deposit $\mathrm{D} 1, \sim 20 \mathrm{~km}^{3}$ for deposit D2, and $\sim 2 \mathrm{~km}^{3}$ for deposit D3. On land, the missing volumes for the last two structures (2 and 3) are $\sim 13$ and $\sim 2 \mathrm{~km}^{3}$ and the lacking volume in the main submarine chute related to event 2 is estimated $\sim 2$ $\mathrm{km}^{3}$. For event 1 , the structure on land would be of $8 \times 6$ $\mathrm{km}$ (using a southern rim identical to that of structure 2) which gives an estimated volume $\sim 25 \mathrm{~km}^{3}$ on the basis of a mean thickness of $500 \mathrm{~m}$ for the sliding mass. For the three events the missing volumes on land are in the same range and a little bit smaller than the estimated volume of the submarine debris avalanche deposits. The difference between the two estimations could be partly explained by 
the expansion of the material due to its fragmentation during flowing.

\subsection{Origin of the Flank Collapse Events}

[41] On Montagne Pelée, as on other volcanoes in the southern Lesser Antilles arc, repetitive flank collapses have occurred in the same southwestern direction, the debris avalanches flowing into the Caribbean sea [Boudon et al., 1999; Deplus et al., 2001]. Several local causes for these successive flank collapse events can be proposed: increase of the load by accumulation of volcanic products, weakening of the flank by intense hydrothermal alteration and/or magmatic injections, dominance of pyroclastic deposit versus massive lava flows. In addition, the structural and regional setting is likely an important control of flank collapses. The southern part of the volcanic arc shows an important east-west asymmetry with a well-developed back arc basin, the Grenada Basin, to the west (Figure 1). The subaerial western flank of the volcano is steeper than the eastern flank. This asymmetry is also obvious on the submarine flanks of Montagne Pelée with slopes of $20 \%$ to the west in contrast to only 5\% to the east. Moreover, the offset of the area of active volcanism (Montagne Pelée) to the west of the island will cause overload of the western flank of the volcano. Enhanced by the steep aerial and submarine slopes of the western flank of the edifice, this overload is likely responsible for repetitive flank collapse events. The resulting horseshoe-shaped structure will create a desequilibrium in the load distribution on one flank of the volcano as a new cone will progressively fill the structure. The floor of the structure thus represents a discontinuity between old indurated deposits and the new nonconsolidated infilling deposits. Hydrothermal fluids and meteoric waters will percolate through the upper, nonconsolidated, deposits and circulate along this. It forms a hydrothermalized layer within the flank of the volcano which constitutes a weak mechanical area that will promote recurrent sliding. Such a system of fluid circulation was identified on the floor of the horseshoe-shaped structure 2 by selfpotential survey [Zlotnicki et al., 1998]. The load necessary for a future flank collapse event will likely diminish because of continuous development of hydrothermalized layers as supported by field evidence of overlapping flank collapse structures which have decreased size with time.

[42] Sea level variations induced by climate change may represent another cause of the repetitive instability of a volcanic edifice on an island arc. The second flank collapse (25 kyr old) occurred during the last glacial period which involved an important lowering of the sea level since 130 ka. In particular, the rate of temperature decrease was high during the period $30-25$ to $18 \mathrm{ka}$, associated with a rapid sea level lowering from $-80 \mathrm{~m}$ to $-140 \mathrm{~m}$ at the glacial maximum [Bard et al., 1990]. Rapid sea level lowering yields an important decrease of the hydrostatic pressure at the bottom of the volcano. If the material is weakly permeable, the pore pressure become larger than the hydrostatic pressure. This effect could decrease the shear strength favoring a flank instability [Hutchinson, 1986].

\subsection{Influence on the Sedimentation in the Grenada Basin}

[43] On the basis of piston cores studies, Reid et al. [1996] have observed that the sedimentation rates in the
Grenada Basin display spatial variations increasing from north to south. There is also some temporal variations: sedimentation rates vary from 4 to $23 \mathrm{~cm} / \mathrm{kyr}$ during the Holocene $(0-12 \mathrm{ka})$ sea level highstand and reach larger values ( 9 to $>25 \mathrm{~cm} / \mathrm{kyr}$ ) during the lowstand of the second period of the Visconsin glaciation $(35-12 \mathrm{ka})$.

[44] Emplacement of several debris avalanches into the Grenada Basin in a short time interval will considerably modify the sedimentation processes due to the large input of volcanoclastic material (cubic kilometers to tens of cubic kilometers) and the generation of secondary debris flows and turbidites. Moreover, the equilibrium profiles of the draining system on land will be drastically modified after a flank collapse thus increasing erosion and detritic sedimentation rates in the Grenada Basin. This erosion rate will also increase during periods of lower sea level as it was the case during the last glacial period $(35-12 \mathrm{ka})$ when the second flank collapse occurred (25 ka) on Montagne Pelée. In addition, successive debris avalanches coming from collapsing volcanoes on nearby Caribbean Islands [Boudon et al., 1999, Deplus et al., 2001] in the last 30,000 years and the intense post flank collapse erosion would have also contributed to major volumes of detritic material in the Grenada Basin and affected the sedimentation rates. Thick sedimentary layers covering the central part of deposit D2 at the mouth of the submarine chute are probably the result of this enhanced detritic sedimentation. Indeed, the main part of deposit D2 is located closer to the submarine flank of the island and at the opening of the chute, which will preferentially channel most of the detritic material eroded from the western flank of the volcano where pyroclastic activity is dominant.

\subsection{Magma Production Rate}

[45] The identification of successive flank collapse events on Montagne Pelée shows that large volumes of volcanic products are lacking on land. It is also the case on the other islands. The magma production rate of $0.1 \mathrm{~m}^{3} / \mathrm{s}$ proposed by Sigurdsson et al. [1980] for all the islands of the arc is thus underestimated. On Montagne Pelée, the volume of volcanic products which lost as a result of the three flank collapse events is estimated at $40 \mathrm{~km}^{3}$ which represents $\sim 70 \%$ of the emerged present volume of Montagne Pelée $\left(50-60 \mathrm{~km}^{3}\right)$. Considering that Montagne Pelée is $0.3 \mathrm{Myr}$ old, the mean magma production rate is $\sim 0.006 \mathrm{~m}^{3} / \mathrm{s}$, using the on-land volume of the present cone, but $0.01 \mathrm{~m}^{3} / \mathrm{s}$ if the collapsed volumes are included. Future estimates of the magma production rate for the entire arc should take into account the large missing volume of volcanic products due to repetitive flank collapse events at different volcanoes.

\subsection{Risk of a Future Event}

[46] During its evolution, Montagne Pelée has been subject to repetitive flank collapse events, involving large volumes (several cubic kilometers to tens of cubic kilometers), with two events occurring in the last 30,000 years. Field data indicate that flank collapses occurred following the growth of a new cone inside the horseshoe-shaped collapse structure left by the previous event. Since the last flank collapse event dating at about $9 \mathrm{ka}$ a new cone has grown on the inclined surface collapse almost filling the entire horseshoe-shaped collapse structure. Consequently, 
the debris avalanche that could result from a future flank collapse event could have catastrophic effects on land and generate a devastating tsunami. In fact, all coastal areas of Martinique as well as that of neighboring islands would be threatened by such a tsunami.

[47] Recognized flank collapse events seems to decrease in volume, whereas span of time between two successive events becomes shorter. If true, next events would be smaller but more frequent. Another possibility is that smaller events could be hidden between the large identified flank collapses.

[48] Acknowledgments. We are grateful to the staff of the Montagne Pelée volcano Observatory for logistical help. We also thank the captain, officers and crew of the R/V L'Atalante for their efficient work at sea and the participating scientists for fruitful discussions. IGN provided to IPGP Volcanological Observatories the DTM of Martinique Island used in this study. We used the GMT software developed by P. Wessel and W. Smith for most of the figures. We thank Jean-Christophe Komorowski for useful comments on a previous version of the paper and Pierre Vincent and Larry Mastin for their helpful reviews. This study was supported by the region Martinique (CPER risques volcaniques) and the CNRS-INSU through several programs. IPGP contribution 1822.

\section{References}

Bard, E., B. Hamelin, and R. G. Fairbanks, U-TH ages obtained by mass spectrometry in corals from Barbados: Sea level during the past 130,000 years, Nature, 346, 391-456, 1990.

Bellon, H., B. Pelletier, and D. Westercamp, Données géochronométriques relatives au volcanisme martiniquais, Antilles Françaises, C. R. Acad. Sci., Ser. D, 279, 457-460, 1974.

Boudon, G., La montagne Pelée, Martinique: Évolution volcanologique, Mém. Soc. Géol. Fr., 163, 231-238, 1993.

Boudon, G., M. P. Semet, and P. M. Vincent, Flank failure-directed blast eruption at Soufrière, Guadeloupe, French West Indies: A 3,000-yr-old Mt St Helens?, Geology, 12, 350-353, 1984.

Boudon, G., M. P. Semet, and P. M. Vincent, Magma and hydrothermally driven sector collapses: The 3100 and 11,500 Y.B.P. eruptions of la Grande découverte (la Soufrière) volcano, Guadeloupe, French West Indies, J. Volcanol. Geotherm. Res., 33, 317-323, 1987.

Boudon, G., J.-C. Komorowski, M. P. Semet, A. Le Friant, and C. Deplus, Frequent volcanic flank-collapses in the Lesser Antilles Arc: Origin and hazards (abstract), Eos Trans. $A G U, 80(46)$, Fall Meet. Suppl., F1142, 1999.

Bouysse, P., D. Westercamp, and P. Andreieff, The Lesser Antilles Island Arc, Proc. Ocean Drill. Program Sci. Results, 110, 29-44, 1990.

Cohen, J. K., and J. J. W. Stockwell, CWP/SU: Seismic Unix release 28: A free package for seismic research and processing, Cent. for Wave Phenomena, Colo. Sch. of Mines, Golden, 1996.

Collot, J. Y., K. B. Lewis, G. Lamarche, and S. Lallemand, Un gigantesque effondrement sous-marin dans la fosse d'Hikurangi, NouvelleZélande: L'avalanche de Ruatoria, résultat de la subduction oblique d'un mont sous-marin, in Réunion Spécialisée Géosciences Marines et Volcanologie, Société Géologique de France, "Marges Océaniques et Magmatisme Associé," p. 30, Soc. Géol. de Fr., Villefranche sur Mer, France, 1999.

Deplus, C., et al., Large-scale debris-avalanche deposits on the western flank of the Lesser Antilles Arc revealed by the Aguadomar cruise (abstract), Eos Trans. AGU, 80(46), Fall Meet. Suppl., F1152, 1999.

Deplus, C., A. Le Friant, G. Boudon, J. C. Komorowski, B. Villemant, C. Harford, J. Ségoufin, and J. L. Cheminée, Submarine evidence for large-scale debris-avalanches in the Lesser Antilles Arc, Earth Planet. Sci. Lett., 192(2), 145-157, 2001.

Holcomb, R., and R. Searle, Large landslides from oceanic volcanoes, Mar. Geotechnol., 10, 19-32, 1991.

Hutchinson, J. N., A sliding-consolidation model for flow slides, Can. Geol. J., 23, 115-126, 1986.

Johnson, B., Blackhawk landslide, California, U.S.A, in Rockslides and avalanches, vol. 1, Natural Phenomena, edited by B. Voight, pp. $481-$ 504, Elsevier Sci., New York, 1978.

Kokelaar, P., and C. Romagnoli, Sector collapse, sedimentation and clast population evolution at an active island-arc volcano: Stromboli, Italy, Bull. Volcanol., 57, 240-262, 1995.

Krastel, S., H. U. Schmincke, C. L. Jacobs, R. Rihm, T. M. Le Bas, and B. Alibés, Submarine landslides around the Canary Islands, J. Geophys. Res., 106, 3977-3997, 2001.
Labazuy, P., Recurrent landslides events on the submarine flank of Piton de la Fournaise volcano (Reunion Island), in Volcano Instability on the Earth and Other Planets, edited by W. J. McGuire, A. P. Jones, and J. Neuberg, Geol. Soc. Spec. Publ., 110, 295-306, 1996.

Lacroix, A., La Montagne Pelée et ses Éruptions, 662 pp., Masson et Cie, Paris, 1904.

Le Friant, A., Importance et origine des déstabilisations de flanc sur les volcans de l'arc antillais, rapport de DEA, Inst. de Phys. du Globe de Paris, Univ. Paris 7, Paris, 1998.

Lénat, J. F., P. Vincent, and P. Bachèlery, The off-shore continuation of an active basaltic volcano: Piton de la Fournaise (Reunion Island, Indian Ocean): Structural and geomorphological interpretation from SeaBeam mapping, J. Volcanol. Geotherm. Res., 36, 1-36, 1989.

Lipman, P. W., and D. R. Mullineaux, (Eds.), The 1980 eruptions of Mount St. Helens, U.S. Geol. Surv. Prof. Pap., 1250, 844 pp., 1981

Lipman, P. W., W. R. Normark, J. G. Moore, J. B. Wilson, and E. Gutmacher, The giant submarine Alika debris slide, Mauna Loa, Hawaii, J. Geophys. Res., 93, 4279-4299, 1988.

Martin-Kaye, P. H. A., A summary of the geology of the Lesser Antilles, Overseas Geol. Miner. Res., 10(2), 172-206, 1969.

Masson, D. G., R. B. Kidd, J. V. Gardner, Q. J. Huggett, and P. P. E. Weaver, Saharian Continental rise: Facies distribution and sediment slides, in Geologic Evolution of Atlantic Continental Rises, C. W. Poag and P. C. de Graciansky, pp. 327-343, Van Nostrand Reinhold, New York, 1992.

Masson, D. G., A. B. Watts, M. J. R. Gee, R. Urgeles, N. C. Mitchell, T. P. Le Bas, and M. Canals, Slope failures on the flanks of the western Canary Islands, Earth Sci. Rev., 57(1-2), 1-35, 2002.

Mattioli, G. S., P. E. Jansma, L. Jaramillo, and A. L. Smith, Sector Collapse in Island Arc Volcanoes: A digital topographic and bathymetric investigation of the Qualibou Depression, St Lucia, Lesser Antilles, Caribbean J. Sci., 31(3-4), 163-173, 1995.

McGuire, W. J., Volcano instability: A review of contemporary themes, in Volcano Instability on the Earth and Other Planets, edited by W. J. McGuire, A. P. Jones, and J. Neuberg, Geol. Soc. Spec. Publ., 110, $1-$ 23, 1996.

Moore, J. G., D. A. Clague, R. T. Holcomb, P. W. Lipman, W. R. Normark, and M. E. Torresan, Prodigious submarine landslides on the Hawaiian ridge, J. Geophys. Res., 94, 17,465-17,484, 1989.

Moore, J. G., W. R. Normark, and R. T. Holcomb, Giant Hawaiian landslides, Annu. Rev. Earth Planet. Sci., 22, 119-144, 1994.

Pratson, L. F., and E. P. Laine, The relative importance of gravity-induced versus current-controlled sedimentation during the quaternary along the mideast U.S. outer continental margin revealed by $3.5 \mathrm{khz}$ echo character, Mar. Geol., 89, 87-126, 1989.

Reid, R. P., S. N. Carey, and D. R. Ross, Late Quaternary sedimentation in the Lesser Antilles island arc, Geol. Soc. Am. Bull., 108, 78-100, 1996.

Robertson, R. E. A., W. P. Aspinall, R. A. Herd, G. E. Norton, R. S. J. Sparks, and S. R. Young, The 1995-1998 eruption of the Soufriere Hills volcano, Montserrat, WI, Philos. Trans. R. Soc. London, 358, 16191637,2000

Roobol, M. J., and A. L. Smith, Stratigraphic studies of Mount Pelé, Martinique, Bull. BRGM, IV(4), 297-304, 1976.

Roobol, M. J., J. V. Wright, and A. L. Smith, Calderas or gravity-slide structures in the Lesser Antilles Island Arc?, J. Volcanol. Geotherm. Res., 19, 121-134, 1983.

Siebert, L., Large volcanic debris-avalanches: Characteristics of source areas, deposits, and associated eruptions, J. Volcanol. Geotherm. Res., 22, $163-197,1984$.

Sigurdsson, H., R. J. S. Sparks, S. N. Carey, and T. C. Huang, Volcanogenic sedimentation in the Lesser Antilles arc, J. Geol., 88, 523-540, 1980.

Smith, W. H. F., and D. T. Sandwell, Global sea floor topography from satellite altimetry and ship depth soundings, Science, 227, 1956-1962, 1997.

Traineau, H., Contribution à l'étude géologique de la Montagne Pelée, Martinique: Evolution de l'activité éruptive au cours de la période récente., 3ème cycle thesis, Univ. Paris XI, Orsay, France, 1982.

Traineau, H., D. Westercamp, and C. Coulon, Mélanges magmatiques à la Montagne Pelée (Martinique). Origine des éruptions de type St. Vincent, Bull. Volcanol., 46, 243-269, 1983.

Urgeles, R., M. Canals, J. Baraza, B. Alonso, and D. Masson, The most recent megalandslides of the Canary Islands: El Golfo debris-avalanche and Canary debris flow, west El Hierro Island, J. Geophys. Res., 102, 20,305-20,323, 1997.

Villemant, B., and C. Fléhoc, U-Th fractionation by fluids in K-rich magma genesis: The Vico volcano, central Italy, Earth Planet. Sci. Lett., 91, 312-326, 1989.

Vincent, P. M., J. L. Bourdier, and G. Boudon, The primitive volcano of mount Pelée: Its construction and partial destruction by flank collapse, J. Volcanol. Geotherm. Res., 38, 1-15, 1989. 
Wadge, G., Morne Patates volcano, southern Dominica, Lesser Antilles, Geol. Mag., 122(3), 253-260, 1985.

Watts, A. B., and D. G. Masson, A giant landslide on the north flank of Tenerife, Canary Islands, J. Geophys. Res., 100, 24,487-24,498, 1995.

Westercamp, D., and H. Traineau, The past 5,000 years of volcanic activity at Mt. Pelée, Martinique (F.W.I.): Implications for assessment of volcanic hazards, J. Volcanol. Geotherm. Res., 17, 159-185, 1983a.

Westercamp, D., and H. Traineau, Carte géologique de la Montagne Pelée (Département de Martinique) au 1/20 000 ème, BRGM, Orléans, France, $1983 b$.

Zlotnicki, J., G. Boudon, J. P. Viodé, J. F. Delarue, A. Mille, and F. Bruère, Hydrothermal circulation beneath Mount Pelée inferred by self potential surveying: Structural and tectonic implications, J. Volcanol. Geotherm. Res., 84, 73-91, 1998.

G. Boudon, A. Le Friant, and B. Villemant, Laboratoire de Physique des Géomatériaux, CNRS UMR 7046, et Observatoires Volcanologiques, Institut de Physique du Globe de Paris, Case 89, 4 place Jussieu, 75252 Paris Cedex 05, France.

C. Deplus, Laboratoire de Gravimétrie et Géodynamique, CNRS UMR 7096, Institut de Physique du Globe de Paris, Case 89, 4 place Jussieu, 75252 Paris Cedex 05, France. (lefriant@ipgp.jussieu.fr) 